\title{
Interaction of aluminium and drought stress on root growth and crop yield on acid soils
}

\author{
Zhong-Bao Yang • Idupulapati Madhusudana Rao • \\ Walter Johannes Horst
}

Received: 7 October 2012 / Accepted: 25 December 2012 /Published online: 15 January 2013

(C) Springer Science+Business Media Dordrecht 2013

\begin{abstract}
Background Aluminium (Al) toxicity and drought stress are two major constraints for crop production in the world, particularly in the tropics. The variation in rainfall distribution and longer dry spells in much of the tropics during the main growing period of crops are becoming increasingly important yield-limiting factors with the global climate change. As a result, crop genotypes that are tolerant of both drought and $\mathrm{Al}$ toxicity need to be developed.

Scope The present review mainly focuses on the interaction of $\mathrm{Al}$ and drought on root development, crop growth and yield on acid soils. It summarizes evidence from our own studies and other published/related work, and provides novel insights into the breeding for the adaptation to these combined abiotic stresses. The primary symptom of Al phytotoxicity is the inhibition of root growth. The impeded root system will restrict the roots for exploring the acid subsoil to
\end{abstract}

Responsible Editor: Philippe Hinsinger.

\section{Z.-B. Yang}

The Key Laboratory of Plant Cell Engineering and

Germplasm Innovation, Ministry of Education,

College of Life Science, Shandong University,

Jinan 250100, People's Republic of China

I. M. Rao

International Center for Tropical Agriculture (CIAT), AA 6713 Cali, Colombia

W. J. Horst $(\square)$

Institute of Plant Nutrition, Leibniz Universität Hannover,

Herrenhaeuser Str. 2, 30419 Hannover, Germany

e-mail: horst@pflern.uni-hannover.de absorb water and nutrients which is particularly important under condition of low soil moisture in the surface soil under drought. Whereas drought primarily affects shoot growth, effects of phytotoxic $\mathrm{Al}$ on shoot growth are mostly secondary effects that are induced by $\mathrm{Al}$ affecting root growth and function, while under drought stress root growth may even be promoted. Much progress has recently been made in the understanding of the physiology and molecular biology of the interaction between Al toxicity and drought stress in common bean (Phaseolus vulgaris L.) in hydroponics and in an Al-toxic soil.

Conclusions Crops growing on acid soils yield less than their potential because of the poorly developed root system that limits nutrient and water uptake. Breeding for drought resistance must be combined with $\mathrm{Al}$ resistance, to assure that drought resistance is expressed adequately in crops grown on soils with acid Al-toxic subsoils.

Keywords Aluminum toxicity $\cdot$ Cell-wall extension · Cell-wall porosity $\cdot$ Phytohormone $\cdot$ Root elongation $\cdot$ Soil acidity $\cdot$ Water relations

\section{Introduction}

Abiotic stresses such as drought, heat, soil acidity and soil salinity could cause extensive losses to global agricultural productivity and thereby impact food security, particularly in the developing countries. Resource-poor farmers are facing a range of challenges such as variability in weather patterns induced by global climate 
change, soil acidity and low soil fertility due to nutrient depletion, and combinations of different abiotic stresses. It was shown that the response of plants to a combination of two different abiotic stresses is unique and cannot be directly extrapolated from the response of plants to each of the different stresses applied individually (Mittler 2006). A comparison made by Mittler (2006) of all major disasters between 1980 and 2004 in the United States caused production loss in excess of $\$ 120$ billion compared to $\$ 20$ billion loss caused by drought alone over the same period. Therefore, a combination of research approaches is urgently needed in order to understand the nature of multiple stress responses and to create avenues for developing plants that are resistant to multiple stresses yet maintaining high yields (Mittler and Blumwald 2010; Atkinson and Urwin 2012).

Soil acidity is one of the most important factors limiting crop production worldwide on approximately $30 \%$ of the world's total land area and as much as $50 \%$ of the world's potentially arable lands (von Uexküll and Mutert 1995). The tropics and subtropics account for $60 \%$ of the acid soils in the world. In tropical areas about $43 \%$ of soils are acidic comprising about $68 \%$ of tropical America, $38 \%$ of tropical Asia, and $27 \%$ of tropical Africa. The factors that contribute to acid soil infertility and subsequent stunted plant growth on acid soils are complex. In acid mineral soils, a variety of individual chemical constraints and interactions among them limit plant growth. For example, in low $\mathrm{pH}$ soils, it is not usually hydrogen ion toxicity which affects plant growth but rather other toxicities, such as aluminium (Al) and manganese, and deficiencies of phosphorus, nitrogen, potassium, calcium, magnesium, and molybdenum (Rao et al. 1993). Aluminium toxicity is particularly severe at soil $\mathrm{pH}$ values of $\leq 5.0$ (Foy 1974).

On many acid soils of the tropics, variability in rainfall distribution and longer dry spells during the main growing period of crops are becoming increasingly important yield-limiting factors (Beebe et al. 2011; Tang et al. 2001; Welcker et al. 2005) with the change in global climate. As a result, crop plants are needed that are tolerant of both drought and Al toxicity. In the common bean-growing regions of the Cerrados of Brazil, it is estimated that $80 \%$ of the area is affected by intermittent drought stress. In the bean-growing acid soils of the Andean region (26\%) with its bimodal rainfall distribution, intermittent drought stress is also very common. In tropical
Africa soil acidity and Al toxicity are intense in several countries and under increasing population pressure, these acid soils are now additionally rapidly being brought into cultivation (Beebe et al. 2011; Wortmann et al. 1998). After the American continent, Asia has the second largest area of acid soils with interactions to seasonal drought in several countries (von Uexküll and Mutert 1995).

Since crop growth largely depends on the ability of roots to explore the soil and absorb water and nutrients, restriction of the development of the root system by $\mathrm{Al}$ will reduce crop yields if water and nutrients are limiting (Goldman et al. 1989; Kell 2011; Trachsel et al. 2010). The use of lime, phosphate fertilizers, organic matter and irrigation is highly productive particularly on acid soils, as practiced in the temperate climates of North America and Europe. However, liming is not an economically realistic alternative in regions with low potential yields because of unfavourable climatic conditions, and in many developing countries particularly in the tropics and subtropics, because the high cost is beyond the ability of low input resource-poor farmers. Also, the utilization of agrochemicals may have undesirable side effects which questions sustainability and threatens the environment (Miklas et al. 2006; Rao et al. 1993). On the other hand, even if liming can raise soil $\mathrm{pH}$ and overcome toxicity problems in the surface soil, the subsoil usually remains unaffected, since deep incorporation of lime is technically difficult and expensive. Therefore, studies on individual and combined stress factors of these two limitations are important to clarify the opportunities and constraints in breeding for adaptation to these soils. In this review we will summarize the knowledge on plant responses to $\mathrm{Al}$ toxicity and drought stress up to the molecular level, and we provide new perspectives into the breeding for the adaptation to these combined abiotic stresses.

\section{Aluminium toxicity and root water-relations}

It has been well recognized that $\mathrm{Al}$ can inhibit water uptake of roots and initiate drought stress (Tamás et al. 2006), mainly resulting from the modification of cell wall $(\mathrm{CW})$ and plasma-membranes properties (Gunsé et al. 1997; Rengel 1996; Wagatsuma et al. 2005; Zhao et al. 1987). For sustained cell elongation and water uptake, CW loosening and synthesis of $\mathrm{CW}$ constitutes is required (Voesenek et al. 2003). Cell expansion requires 
a driving force for water uptake by decreasing the turgor through CW stress relaxation produced by wall loosening (Schopfer 2006). Elongation of plant cells is controlled by the extensibility of CWs (McQueen-Mason and Rochange 1999). Several studies have revealed that the CW extensibility was reduced by $\mathrm{Al}$ (Barceló et al. 1996; Gunsé et al. 1997; Ma et al. 2004; Tabuchi and Matsumoto 2001). Gunsé et al. (1997) found that $\mathrm{Al}$ increased the hydraulic conductivity of an Al-resistant variety in maize (Zea mays L.) but decreased the hydraulic conductivity and $\mathrm{CW}$ extensibility of an Alsensitive variety, suggesting that the influence of $\mathrm{Al}$ on the mechanical properties of the $\mathrm{CW}$ may play a prominent role in the Al-induced inhibition of root elongation. The rapid binding of $\mathrm{Al}$ in the root apoplast may reduce $\mathrm{CW}$ porosity and thus the mobility of higher molecular solutes. This has led to the hypothesis that Al may directly affect the root hydraulic conductivity (Kruger and Sucoff 1989; Maison and Bertsch 1997; Sivaguru et al. 2006). However, this has yet to be proven experimentally (George et al. 2012). Using artificial pectin membranes, Blamey et al. (1993) demonstrated that the binding of $\mathrm{Al}$ to pectin strongly reduced water permeability of the membranes. Recently, hemicellulose rather than pectins have been implicated in $\mathrm{Al}$ binding in CWs (Yang et al. 2011a). Further studies in Arabidopsis thaliana (L.) Heynh provided evidence that $\mathrm{Al}$ interacts specifically with xyloglucans (Zhu et al. 2012). The formation of an Al-xyloglucan complex in the $\mathrm{CW}$ inhibits wall loosening in the elongation zone of roots and thus contributes to inhibition of root elongation by $\mathrm{Al}$. However, the role of xyloglucan-Al interaction in affecting water permeability of CWs needs to be explored.

Besides the $\mathrm{CW}, \mathrm{Al}$ also rapidly affects the properties of the plasma membrane (Ishikawa and Wagatsuma 1998). Interaction of $\mathrm{Al}$ with membrane components modifies the membrane structural properties such as fluidity and permeability (Khan et al. 2009; Vierstra and Haug 1978; Wagatsuma et al. 2005). In the root cortical cells of Northern red oak (Quercus rubra L.), it was found that $\mathrm{Al}$ decreased the membrane permeability to water (Chen et al. 1991; Zhao et al. 1987). Water absorption into the root cells is also controlled by the water potential gradient which acts as the driving force for water uptake and build-up of turgor which is a prerequisite for cell extension. In Al-resistant wheat (Triticum aestivum L.) genotypes (Atlas 66 and ET8) the Al-induced increase of soluble sugars in the root cells can compensate for the net loss of osmotica resulting from the release of malate and $\mathrm{K}^{+}$(Ryan et al. 1995), thus maintaining turgor and enabling the root cells to take up water and to maintain root elongation in presence of $\mathrm{Al}$ (Tabuchi et al. 2004).

Furthermore, gene expression analysis has revealed that $\mathrm{Al}$ suppressed the expression of the tonoplast aquaporins in rye (Secale cereal L.) (Milla et al. 2002) and induced the expression of the dehydrin gene DHN4, a well-known marker for water deficit in roots (Tamás et al. 2006).

\section{Root-growth response of plants to aluminium toxicity and drought}

Aluminium toxicity is the most important factor limiting plant growth on acid mineral soils (Carver and Ownby 1995; Foy 1984). A typical and most sensitive symptom of $\mathrm{Al}$ toxicity is a rapid (minutes) inhibition of root elongation (Delhaize and Ryan 1995; Horst et al. 1992), resulting in a reduced and damaged root system that limits uptake of nutrients and water (Kochian et al. 2004; Fig. 1). The root apex is the major perception site of $\mathrm{Al}$ toxicity (Ryan et al. 1993). In the root apical tissues, Sivaguru and Horst (1998) specified that the distal part of the transition zone (DTZ, 1-2 mm) is the most Al-sensitive apical root zone in maize. Application of Al to the DTZ but not the elongation zone (EZ) reduced cell elongation in the EZ to the same extent as application to the entire $10 \mathrm{~mm}$ root apex. Further evidence demonstrated that Al stress increased the accumulation of auxin in the root cap and root apical meristematic zone (MZ) (Kollmeier et al. 2000; Sun et al. 2010), while Al inhibited the basipetal transport of auxin (Hasenstein and Evans 1988; Kollmeier et al. 2000; Shen et al. 2008), supporting the proposal that the basipetal auxin signal transport was involved in the regulation of Al-stress signal transduction between the $\mathrm{TZ}$ and EZ (Fig. 1). The importance of the $\mathrm{TZ}$ as a main target of $\mathrm{Al}$ was also confirmed in common bean (Phaseolus vulgaris L.) by Rangel et al. (2007). However, in contrast to maize, in common bean both the transition zone (TZ, 1$2 \mathrm{~mm}$ ) and elongation zone (EZ) are targets of $\mathrm{Al}$ injury.

Root elongation is also inhibited under water stress, but there are two main differences between $\mathrm{Al}$ and drought stress: (i) under drought stress shoot growth is much more affected than root growth (reviewed by Yamaguchi and Sharp 2010), whereas short and medium-term Al excess may strongly reduce root growth without affecting shoot growth (Kochian et al. 


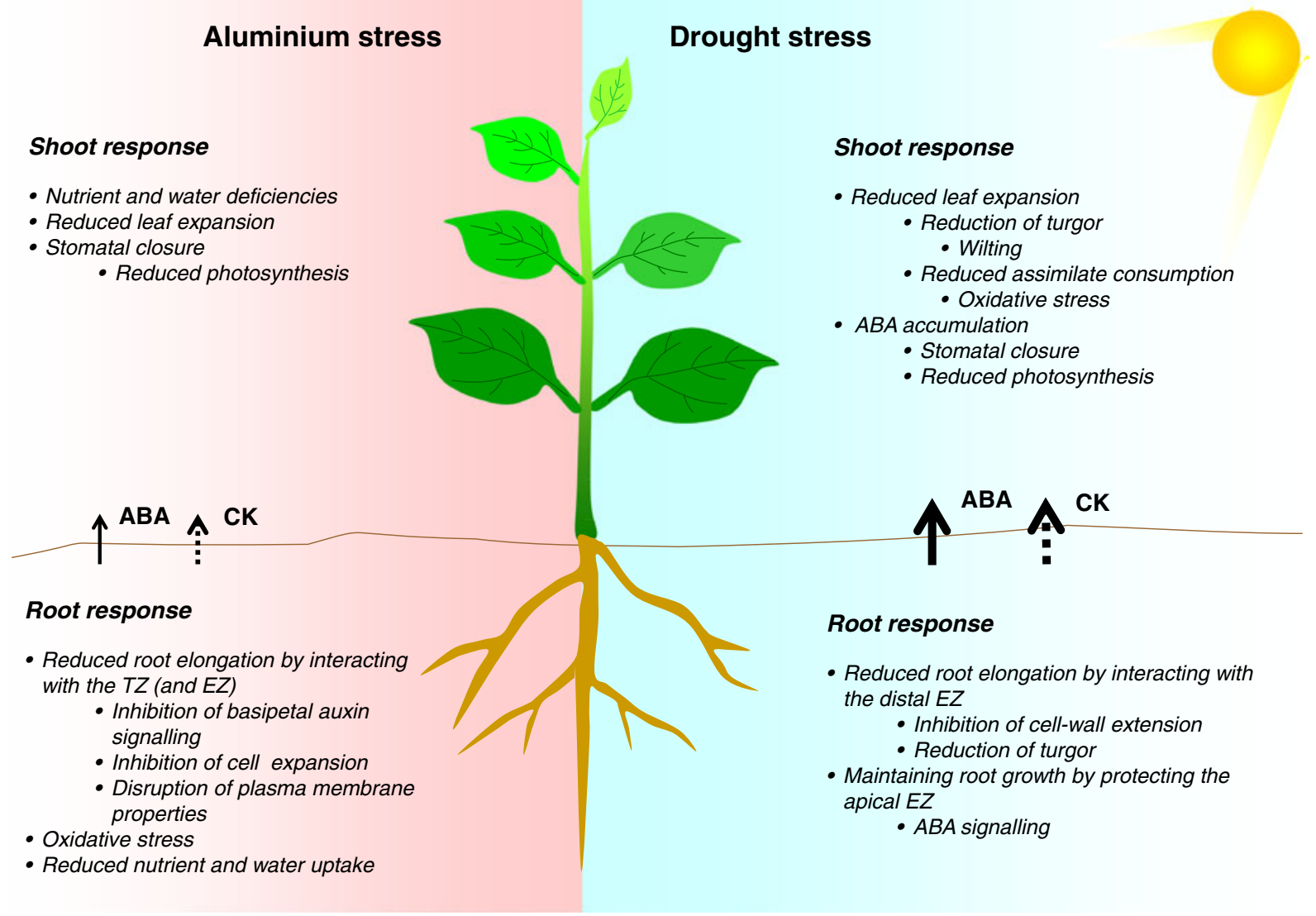

Fig. 1 Schematic representation of factors responsible for root and shoot-growth inhibition by $\mathrm{Al}$ toxicity (left) and drought stress (right). Short-term Al toxicity inhibits root elongation by interacting with the transition zone (TZ) and potentially the elongation zone (EZ) through the inhibition of basipetal auxinsignal transport, cell expansion and disruption of plasma membrane properties. Long-term Al stress causes oxidative stress and reduce nutrient and water uptake of roots, and subsequently results in nutrient and water deficiencies, reduction of leaf expansion, stomatal closure and reduced net photosynthesis of leaves. Drought stress inhibits root elongation by interacting

2004; Yang et al. 2009); (ii) Al toxicity reduces cell elongation along the entire elongation zone (Kollmeier et al. 2000), whereas under water deficit or osmotic stress cell elongation is inhibited only in the basal and central elongation zones (definition of zones according to Ishikawa and Evans 1993), but maintained toward the root apex (Sharp et al. 1988) in the distal and apical elongation zones (Shimazaki et al. 2005) (Fig. 1).

The maintenance of root elongation in the root apex is mainly achieved by three potential mechanisms: osmotic adjustment, modification of cell-wall extension and the accumulation of abscisic acid (ABA) (Sharp et with the distal EZ through inhibition of cell-wall extension and reduction of turgor, while maintaining root growth by protecting the apical EZ through abscisic acid (ABA) signaling. In shoots drought stress reduces leaf expansion through the reduction of turgor and assimilate consumption leading to leaf wilting and oxidative stress, respectively, whereas the ABA accumulation causes stomatal closure and reduced net photosynthesis of leaves. ABA and cytokinin (CK) signalling might be involved in root to shoot communication under both $\mathrm{Al}$ and drought stress. Continuous and dashed arrows indicate enhanced or inhibited fluxes, their thickness the size of the flux

al. 2004; Yamaguchi and Sharp 2010; Fig. 1). The different response of root elongation under $\mathrm{Al}$ and drought stress appears of ecological advantage, because inhibition of root growth by $\mathrm{Al}$ in the Al-toxic subsoil allows the plants to more efficiently forage the more nutrient-rich surface soil for nutrients and water (Hairiah et al. 1995), while the maintenance of root growth under drought allows the roots to grow into the subsoil for better foraging of the subsoil for water and nutrients (Whitmore and Whalley 2009).

However, it has to be kept in mind that in soils particularly under field conditions, declining soil 
moisture does not only induce water deficit in the roots but also increase the mechanical impedance of the soil which, additionally, strongly limits root growth (see comprehensive review by Bengough et al. 2011). There is only little information available on the interaction between mechanical impedance and Al toxicity on root growth. Foy et al. (1999) related the failure of Alresistant crop genotypes to restricted root development in Al-toxic acid subsoil to its high bulk density. Horst et al. (1990) addressed this aspect and suggested, based on the comparison between hydroponically and sandculture grown plants, that mechanical impedance alleviates Al toxicity by enhancing the release of high molecular weight root exudates (mucilage) protecting the root apex from $\mathrm{Al}$ injury (Horst et al. 1982).

The effect of combined drought and $\mathrm{Al}$ stresses on root growth has hardly been addressed in the past. It has been postulated that a decrease in soil-water content during drought may increase the toxic $\mathrm{Al}$ concentration in the soil solution thus enhancing Al toxicity in plants (Schier and McQuattie 2000) which was confirmed by Yang et al. (2012) (Fig. 2). In Scots pine and Norway spruce, water deficit more strongly reduced the root elongation-rate and numbers of growing roots in a soil with $\mathrm{pH} 3.8$ and high levels of $\mathrm{Al}$ than in a pH 5.9 soil and lower Al levels (Bartsch 1987). Krizek and Foy (1988a) and Krizek et al. (1988) observed that drought exacerbated the effects of Al toxicity in plants, and increasing the soil-moisture level reduced Al toxicity in barley (Hordeum vulgare L.) and sunflower (Helianthus annuus L.). Schier and McQuattie (2000)

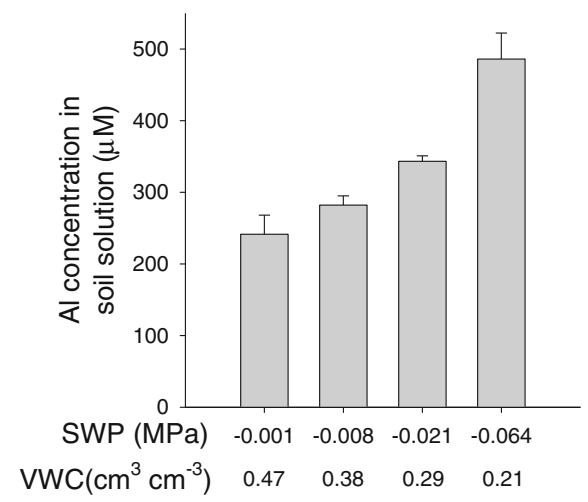

Fig. 2 Total soluble aluminium concentration in the soil solution under different levels of soil moisture. The soil solution from the incubated soil treated with $2 \mathrm{~g} \mathrm{AlCl}_{3} \cdot 6 \mathrm{H}_{2} \mathrm{O}$ was obtained by centrifugation. Bars represent means $\pm \mathrm{SD}, n=3$. SWP: soil-water potential; VWC: volumetric water content. From Yang et al. (2012) found that at low soil moisture the growth of ectomycorrhizal pitch pine (Pinus rigida Mill.) seedlings was more inhibited by $\mathrm{Al}$, and $\mathrm{Al}$ toxicity symptoms in roots were more severe. However, enhanced Al toxicity at low soil moisture was not in agreement with their results that drought stress reduced the $\mathrm{Al}$ concentration in leaves of sunflower (Krizek and Foy 1988b) and roots of ectomycorrhizal pitch pine (Schier and McQuattie 2000). Drought-induced lower Al accumulation in plants has been reported in Norway spruce seedlings (Slugeňová et al. 2011), leaves of evergreen Mediterranean oak (Quercus ilex L.) (Sardans and Peñuelas 2007) and in common bean (Yang et al. 2010). Using polyethylene glycol (PEG 6000) to simulate drought stress in hydroponics, Yang et al. (2010) found that PEG 6000 strongly blocked the $\mathrm{Al}$ accumulation in the root tips and consequently reduced the toxic Al-induced inhibition of root elongation in common bean. This PEG 6000-caused exclusion of Al from the root tips of common bean could not be explained by a decrease of cell-wall negativity determined by the concentration of cell-wall pectins and its degree of methylation (Eticha et al. 2005; Schmohl and Horst 2000; Yang et al. 2008), nor by enhanced citrate exudation from the root apex which has been shown to play a key role in $\mathrm{Al}$ exclusion and resistance in bean (Miyasaka et al. 1991; Yang et al. 2000; Rangel et al. 2010). Aluminium exclusion was mainly caused by the alteration of $\mathrm{CW}$ porosity resulting from PEG 6000-induced dehydration of the root apoplast (Yang et al. 2010).

It is important to note that PEG 6000 has been amply used as an ideal non-absorbed osmoticum to induce osmotic stress owing to its low penetration into the apoplastic and symplastic space because of its high molecular weight and size (Carpita et al. 1979; Hohl and Schopfer 1991), and thus it allows mimicking the response of plants to drought stress in hydroponic studies. It has been reported early in the 1960s that PEG can be used to modify the osmotic potential of nutrient solution in hydroponics and thus induce water deficit in a relatively controlled manner (Lagerwerff et al. 1961). Higher molecular weight $(M W \geq 6000)$ of PEG solution mimic dry soil more closely than solutions of low-MW osmotica such as mannitol, sorbitol, inorganic salts or PEG of MW less than 6000, which infiltrate the CW and cause damages to the cell membrane (Fan and Blake 1997; Veslues et al. 1998). The consistency of the expression of 11 among 12 selected $\mathrm{CW}$ and osmotic stress-associated genes by PEG and 
by drought in soil in root tips of common bean (Yang et al. 2011b; 2012) supports the use of PEG 6000 in hydroponics in determining short-term drought stress responses of root apices at the molecular level. However, it appears that the expression levels of most of genes changes more in root apices exposed to dry soil at a water potential of $-0.31 \mathrm{MPa}$ than at a water potential of $-0.60 \mathrm{MPa}$ in hydroponics. These great differences might result from the possibility to acclimate to osmotic stress (PEG 6000) in hydroponic culture, allowing sufficient water uptake to resume root elongation partly within $24 \mathrm{~h}$, whereas in dried soil the adaptation to water deficit fails. This hypothesis can well explain the difference in the interactive effect of Al toxicity and drought stress between the two experimental approaches (PEG-simulated drought in hydroponics, Yang et al. 2010 and dried acidic soil, Yang et al. 2012): whereas PEG-simulated drought alleviated inhibition of root elongation by $\mathrm{Al}$, low soil moisture enhanced root-growth inhibition in Al-toxic soil (Fig. 3a).

The PEG-induced inhibition of $\mathrm{Al}$ accumulation in the root tips of common bean (Yang et al. 2011c) was consistent with PEG-suppressed Al-induced expression of the multidrug and toxin extrusion (MATE) family protein gene (Fig. 3b) confirming the PEG-induced alleviation of $\mathrm{Al}$ toxicity at the molecular level. Also, the reversion of another reliable Al-sensitive indicator (callose formation, Wissemeier et al. 1987; Staß and Horst 2009) in the root tips by low soil moisture strongly supported this result under soil conditions (Fig. 3c; Yang et al. 2012). The Al-activated citrate transporter MATE has been suggested to be responsible for citrate exudation from the root tips and thus $\mathrm{Al}$ resistance in several plant species (Furukawa et al. 2007; Magalhaes et al. 2007; Maron et al. 2010; Yang et al. 2011b; Yokosho et al. 2011). In common bean, the expression of MATE is a prerequisite for citrate exudation, but the build-up of $\mathrm{Al}$ resistance in genotype Quimbaya in comparison to the Al-sensitive genotype VAX-1 is mainly dependent on the capacity to sustain the synthesis of citrate for the maintenance of the cytosolic citrate pool that enables continuous exudation (Eticha et al. 2010; Rangel et al. 2010). The MATE gene behaves as an Al sensor in common bean, independent of the $\mathrm{Al}$ resistance of the genotype (Eticha et al. 2010).
Fig. 3 Root-elongation rate (a), callose content (b) and the expression of MATE (c) and $A C C O(\mathbf{d})$ in the root tips $(1 \mathrm{~cm})$ of common bean genotype VAX 1 as affected by soil moisture and $\mathrm{Al}$ supply $\left(\mathrm{g} \mathrm{AlCl}_{3} \cdot 6 \mathrm{H}_{2} \mathrm{O} \mathrm{kg}^{-1}\right.$ soil). Two-day-old seedlings were grown in soil for $24 \mathrm{~h}$. Bars represent means $\pm \mathrm{SD}$, $n=12$ for (a), $n=4$ for (b), and $n=3$ for (c and d). qRTPCR was performed using the $\beta$-tubulin gene as internal standard. For the ANOVA (two-way), **, and *** denote significance at $P$ $<0.01$, and $P<0.001$, respectively. SWP: soil-water potential; VWC: volumetric water content. Compiled from Yang et al. (2012)
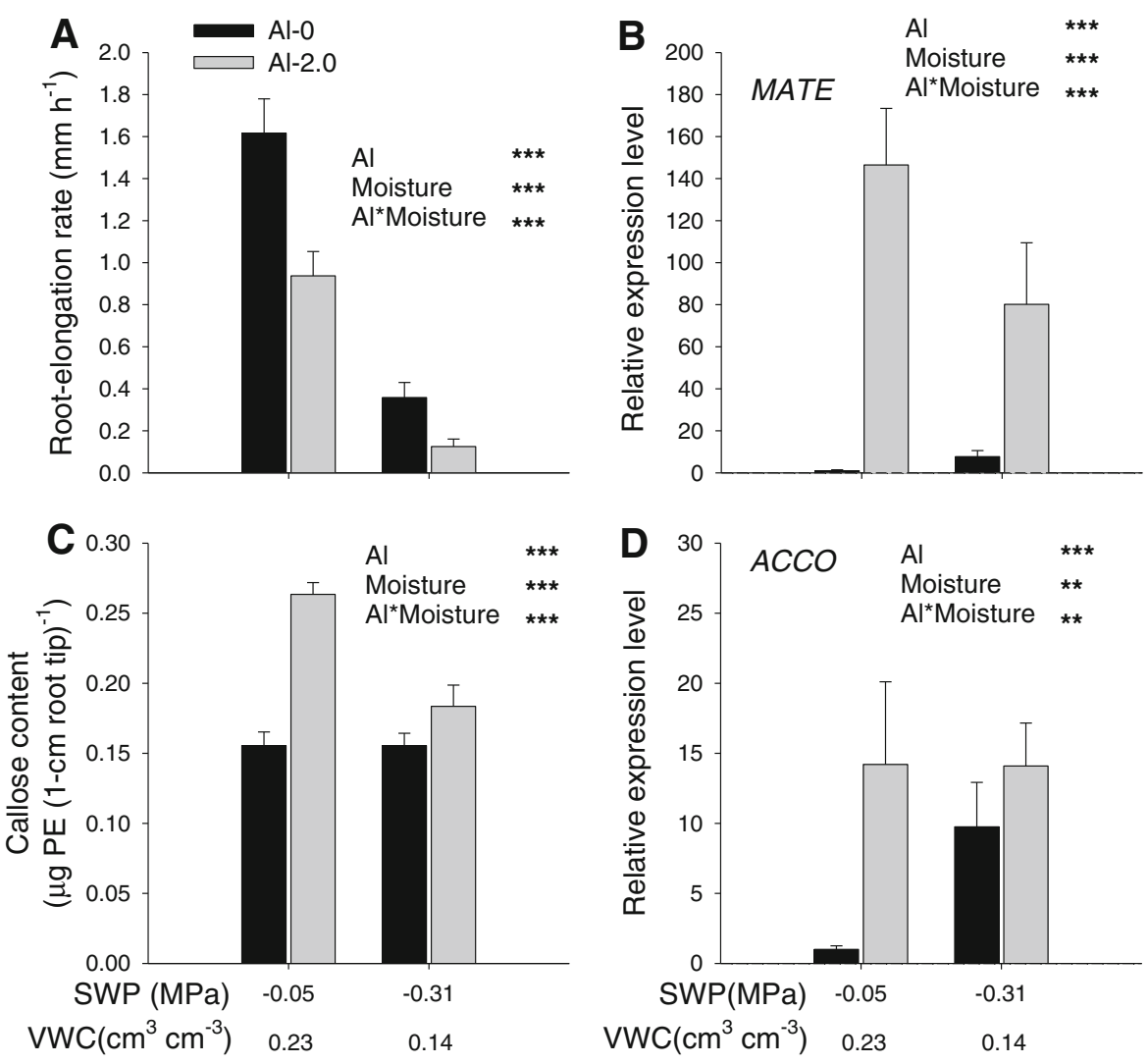
In addition, it has been speculated that the expression of the gene coding for 1-aminocyclopropane-1carboxylic acid oxidase (ACCO) catalysing the last step of ethylene biosynthesis (Wang et al. 2002) contributes to the Al-induced inhibition of root elongation (Eticha et al. 2010; Sun et al. 2007). The high sensitivity of $A C C O$ gene expression in response to $\mathrm{Al}$ in common bean was further verified by a significant correlation between $A C C O$ expression, root elongation and $\mathrm{Al}$ concentration in the root tips (Yang et al. 2011b). However, different from the MATE gene, low soil-moisture stress also induced the expression of the $A C C O$ gene in the root tips of bean and thus the expression remained high at $\mathrm{Al}$ and drought dual stresses (Fig. 3d; Yang et al. 2012).

The fact that in contrast to the hydroponic studies with PEG 6000, under soil conditions, combined drought and Al stresses aggravated the inhibition of root elongation beyond the effects of the individual stresses in an additive manner in common bean does not support the suggestion (Schier and McQuattie 2000) that low soil moisture-increased Al concentration in the soil solution (see Fig. 2) may enhance Al rhizotoxicity in plants. Circumstantial evidence rather indicated that the remaining $\mathrm{Al}$ in the root tips renders the root apex more drought-sensitive (Yang et al. 2012). Therefore, these results support the hypothesis that at low soil moisture in acid soils Al may prevent the acclimation of roots to drought and inhibit root growth into deeper soil layers thus restricting the acquisition of water from the subsoil. This hypothesis is supported by the results of Goldman et al. (1989) who found that soybean (Glycine $\max$ L.) plants grown in soil at combined $\mathrm{Al}$ and drought stress had lower levels of leaf relative water content, water potential, and lower transpiration rates than individual stress factors. Butare et al. (2011) also showed that in an acid Al-toxic soil, combined $\mathrm{Al} /$ drought stresses led to a more severe inhibition of root growth in Phaseolus acutifolius A. Gray and the Mesoamerican common bean genotypes. By analysis of the combined effect of short-term water-deficit stress and $\mathrm{Al}$ toxicity on citrate exudation from soybean roots, Nian et al. (2004) showed that the individual stress mainly impeded root growth, while combined stresses reduced both root and shoot growth. The Al-resistant genotype PI416937 exuded more citrate from roots than the Al-sensitive soybean genotype Young after 2 days of recovery from combined stresses.

\section{Shoot-growth response of plants to aluminium toxicity and drought}

In recent years, there has been a significant progress on our understanding of the shoot-growth responses of plants to aluminum toxicity and drought (Aftab et al. 2010; Beebe et al. 2009, 2010; Blum 2010; Chaves et al. 2003; Chen 2006; Manavalan et al. 2009; Okiyo et al. 2010; Wang et al. 2006; Zhang et al. 2007). The effect of $\mathrm{Al}$ and drought on shoot and root growth and the factors responsible for the inhibition of root and shoot growth owing to $\mathrm{Al}$ toxicity and drought stress are depicted in Fig. 1. There is a fundamental difference in the response of shoot growth to $\mathrm{Al}$ and drought: since in most plant species $\mathrm{Al}$ is not readily translocated from the roots to the shoots (Al excluders), $\mathrm{Al}$ effects on shoot growth are thus secondary effects induced by $\mathrm{Al}$ affecting root growth and function (George et al. 2012). In contrast, under drought stress the development of the root system is usually less inhibited than shoot growth, and may even be promoted (Sharp and Davies 1989; Sharp et al. 2004). For several crops such as maize, soybean, cotton (Gossypium hirsutum L.) and squash (Cucurbita maxima Duch.) the primary root maintains substantial elongation rates at water potentials lower than $-1.5 \mathrm{MPa}$, whereas shoot growth is completely inhibited at much higher water potentials (Spollen et al. 1993).

Given the complexity of indirect factors possibly involved in Al-induced shoot growth inhibition it is not surprising that the described common responses of shoots to Al toxicity include: cellular and ultrastructural changes in leaves, increased rates of diffusion resistance, reduction of stomatal aperture, decreased photosynthetic activity, chlorosis and necrosis of leaves, decrease in total leaf number and size, and a decrease in shoot biomass (Mossor-Pietraszewska 2001). Al toxicity affects growth and gas exchange (Pereira et al. 2000; Simon et al. 1994a, b), carbohydrate content (Graham 2002), mineral nutrition (George et al. 2012; Lidon et al. 1999), organic acid metabolism (Watanabe and Osaki 2002) and nitrogen metabolism (Xiao 2002) of the shoot.

A primary response of plants to drought stress is the inhibition of shoot growth. The reduction in water availability from low soil moisture results in a complex response in shoot growth characterized by a decrease in the water potential of plant tissues, particularly in growing tissues, which leads to a variety of modifications in different plant processes (Blum 2010). These 
include growth inhibition, accumulation of ABA and osmoprotecting solutes, stomatal closure, reduced transpiration and photosynthetic rates, induction of mechanisms of scavenging reactive oxygen species (ROS), and changes in the accumulation levels of proteins and mRNAs (Chaves et al. 2003; Manavalan et al. 2009; Rosales et al. 2012). Recent work on common bean shoot-growth responses to drought indicated that remobilization of photosynthates from vegetative shoot structures to pods, and from pod wall to grain is an important mechanism of retaining yield under drought (Beebe et al. 2010; Rao et al. 2009). If drought stress is not relieved, it leads to interrupted reproductive development, premature leaf senescence, wilting, desiccation and death (Neumann 2008). Decrease in leaf water potential during stress induces stomatal closure, leading to a reduction of $\mathrm{CO}_{2}$ availability and consequently a decline in net photosynthetic rate and water-use efficiency (Bota et al. 2004; Chaves et al. 2003). The decline in net photosynthetic rate could lead to decrease in shoot growth rate and dry matter production (Lawlor and Tezara 2009). The inhibition of leaf growth and net photosynthetic rate under drought stress could allow diversion of essential solutes from growth requirements to stress-related house-keeping functions, such as osmotic adjustment that improves cell-water retention and turgor maintenance.

Signal molecules produced in the root in addition to water and nutrients are important mediators of shoot physiological processes. Root-to-shoot signalling is often considered to be important in regulating shoot growth and water use when soil conditions change (Dodd 2005). Hormones such as ABA and cytokinins (CKs) have been implicated in the root-shoot signaling, either acting in isolation or concomitantly (Chaves and Oliveira 2004; Davies et al. 2005; Schachtman and Goodger 2008; Wilkinson et al. 2012). ABA has been identified as one of the major chemical signals involved in stomatal functioning by the regulation of longdistance transport and modulation of ABA concentration at the guard cells (Chaves et al. 2003). However, increased CK concentration in xylem sap decreases stomatal sensitivity to ABA and promotes stomatal opening directly (Wilkinson and Davies 2002). Sivaguru et al. (2003) speculated that Al may interfere with ABA transport and signaling, and thus lead to the closure of stomata. The potential involvement of ABA and CK in rootshoot communications under $\mathrm{Al}$ and drought stresses are simplistically depicted in Fig. 1.

\section{Understanding the interaction of aluminium/ drought stresses on root growth}

\section{Cell-wall porosity}

The plant cell-wall is a composite structure consisting of a cellulose-hemicellulose framework embedded within a matrix of pectins and proteins. This chemical structure determines its plastic and elastic properties allowing deformation in different directions (Carpita and Gibeaut 1993). Under water deficit the loss of water in the apoplast will result in a collapse of wall structure, and consequently reduction of wall porosity and polymer adhesion or cross-linking (Fig. 4; Moore et al. 2008b; Yang et al. 2011c).

The pores of the $\mathrm{CW}$ are the first barrier for mobile solutes such as ions, proteins, and water penetrating the wall (Brett and Waldron 1996), and plant cells interact with their environment through the porous network of the CW (Carpita et al. 1979). The pore size mainly depends on CW structure, hydrophobicity, CW chemical composition, and physical properties (Carpita et al. 1979; Chesson et al. 1997). According to Baron-Epel et al. (1988) the pore size of the CW is mainly controlled by the pectic matrix. Any change in the factors affecting the pectic matrix may change the porosity. For example, it was reported that low temperature decreased the pore size of the $\mathrm{CW}$ by modifying CW composition (Bauchot et al. 1999; Rajashekar and Lafta 1996). Boron can affect the pore size by influencing the borate ester cross-linked pectic network in the primary CW (Fleischer et al. 1999). Enhanced Al toxicity in boron-deficient plants could be related to the pore size of the CW (Horst et al. 2010). The pectic side chains may also control CW porosity as has been suggested by Brummel (2006). Water stress increased the formation of pectic side chains in a drought-tolerant cultivar of wheat (Leucci et al. 2008). Our finding of the PEG-induced reduction of CW pectin content in the root tips of common bean suggest that osmotic stress may interfere with the CW structure consequently resulting in the rearrangement of the wall polymers and thus affecting CW porosity (Yang et al. 2010). The reduced CW porosity resulting from the PEG-induced osmotic stress restricts the penetration of cations into the apoplast depending on the hydrated ionic radius: the higher the hydrated ionic radius, the lower was the ion accumulation in the root tips or ethanol-isolated CWs of root tips $\left(\mathrm{Al}^{3+}>\mathrm{La}^{3+}>\right.$ 

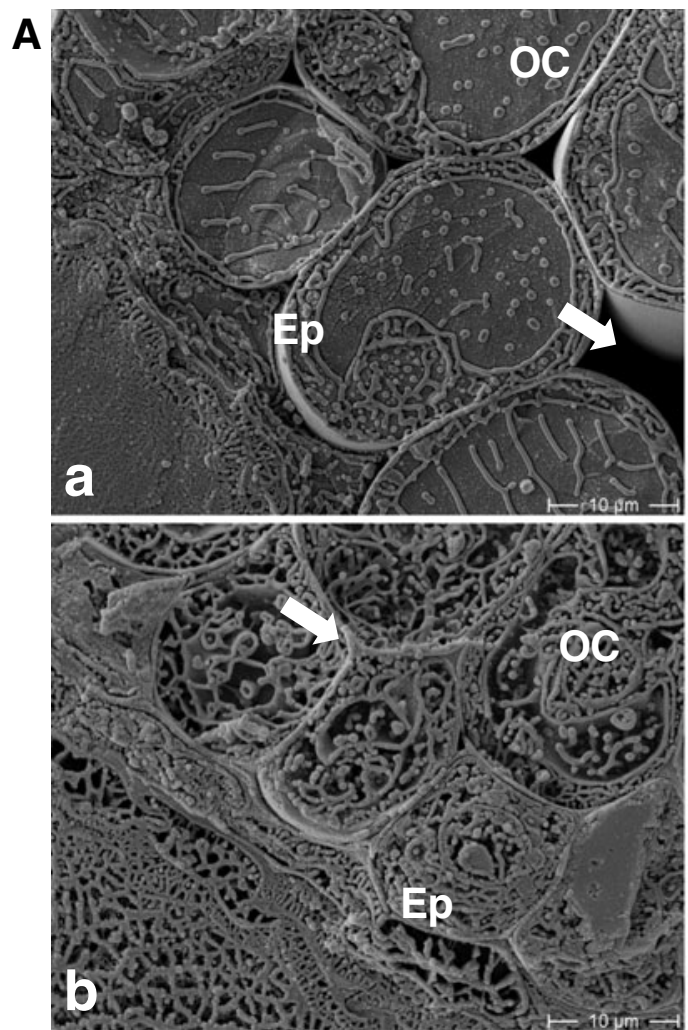

B

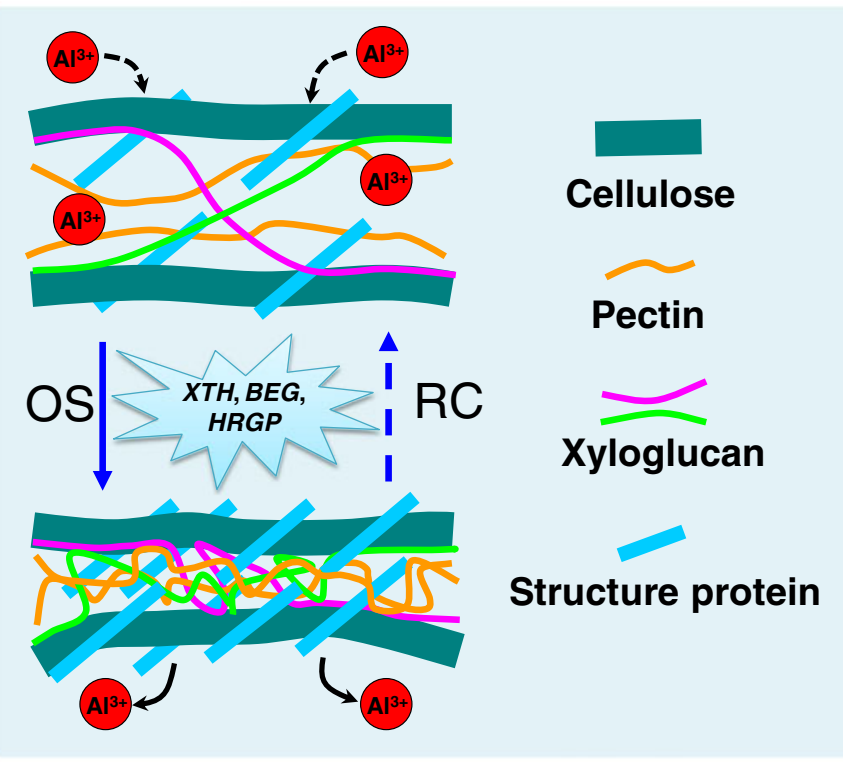

Fig. 4 A Freeze-fracture scanning electron micrographs of roottip cross-sections (1-5 mm from the root apex) of common bean genotype VAX 1 grown for $4 \mathrm{~h}$ in the absence $(a)$ or presence $(b)$ of PEG (150 $\mathrm{gL}^{-1}$ PEG $6000,-0.60 \mathrm{MPa}$ osmotic potential, $\mathrm{pH}$ 4.5). Pictures show the epidermis (Ep) and one outer cortical cell layer (OC). Arrows indicate the presence $(a)$ or absence $(b)$ of intercellular spaces between the epidermis and the outer cortical cell layer. Scale bars $=10 \mu \mathrm{m}$. B A model representing the effect of osmotic stress (OS) on the cell wall (CW) structure and $\mathrm{Al}$

$\mathrm{Sr}^{2+}>\mathrm{Rb}^{+}$) (Yang et al. 2010). Using freeze-fracture scanning electron microscopy (FSEM) Yang et al. (2010) showed that PEG 6000 but not PEG 1000 strongly reduced the intracellular spaces of the epidermis and the outer cortical cell layers in the root tips of common bean (Fig. 4a), indicating that PEG 6000 causes dehydration of the root apoplast more than PEG 1000 with its higher mobility in the apoplast owing to its smaller hydrodynamic radius (Kuga 1981; Yang et al. 2010).

Under water deficit the protection of plant cells from $\mathrm{CW}$ collapse and subsequent damage requires the maintenance of CW flexibility. Studies with resurrection plants have demonstrated that $\mathrm{CW}$ flexibility can be modified by a constitutively high content of pectin-associated arabinans (Moore et al. 2006, binding, and the possible role of CW modification-related genes or structure proteins in the OS-induced change in $\mathrm{CW}$ porosity and thus $\mathrm{Al}$ binding to the $\mathrm{CW}$ in common bean plants. The solid and dashed arrows indicate the recovery (RC) from osmotic stress, respectively. XTH: xyloglucan endotransglucosylase/hydrolases; BEG: beta-1,3-glucanase; HRGP: hydroxyprolin-rich glycoprotein. Based on Yang et al. (2010, 2011c)

2008a). Water is the most abundant component of the CW (approximately 75-80\% water) and decides on its pectic hydro-gel properties and thus viscoelastic nature (Cosgrove 1997). Loss of water from the CW matrix can seriously disrupt the polymer organization. The highly hydrophilic pectin can attract and sequester water and may behave as a lubricant between individual CW layers and thus avoid the CW collapse and damage from water loss. In addition, the hydrophilic protein dehydrin, which is supposed to be localized in the $\mathrm{CW}$, may also play a role similar to pectin in preventing the $\mathrm{CW}$ from water deficit-caused mechanical fracture (Layton et al. 2010), maintaining the elastic extension (reversible stretching) properties and, consequently, the porosity of the $\mathrm{CW}$. Also, $\mathrm{CW}$ structural proteins such as the hydroxyproline-rich 
glycoprotein extensin, can cross-link with other polymers in the CW and thus affect $\mathrm{CW}$ porosity (Brett and Waldron 1996). A HRGP gene encoding hydroxyprolinrich glycoprotein has been proposed to participate in the modification of $\mathrm{CW}$ porosity during PEG-induced osmotic stress in common bean (Fig. 4b; Yang et al. 2011c).

Loss of water from the CW matrix can bring the polymers into close proximity to each other, and thus cause polymer adhesion or cross-linking under water deficit (Moore et al. 2008b). Several CW-modifying proteins such as expansins, xyloglucan endotransglucosylase/hydrolases (XTHs), endoglucanases and pectin methylesterases (PMEs) play key roles in the modification of CW structure and thus porosity (recently reviewed by Sasidharan et al. 2011). In Arabidopsis, microarray analysis indicated that most of the $\mathrm{CW}$-associated genes including genes encoding those above-mentioned CW-modifying proteins are down-regulated under water deficit (Bray 2004) supporting the results generated from transcriptome analysis of the drought (PEG stress)-subjected root apices of common bean by SuperSAGE (serial of analysis of gene expression) (Yang et al. 2011c). XTHs play key roles in modification of $\mathrm{CW}$ structure and extensibility through the cleavage and re-formation of bonds between xyloglucan chains (Bray 2004; Rose et al. 2002). The potential role of XTHs in the modification of $\mathrm{CW}$ porosity and $\mathrm{Al}$ binding to the $\mathrm{CW}$ during PEG-induced osmotic stress has been proposed by Yang et al. (2011c), who found that the expression of $X T H$ genes was suppressed by PEG and rapidly reversed by removal of PEG stress, consistent with the change of $\mathrm{Al}$ accumulation in the root tips of common bean (Yang et al. 2010). In addition, the CW-loosening enzyme beta-1,3-glucanase (BEG) has been also predicted to be involved in the PEG-induced alteration of CW porosity (Yang et al. 2011c). Further studies are required to assess the role of those $\mathrm{CW}$-modifying proteins in the alteration of $\mathrm{CW}$ porosity to verify the hypothesis forwarded in Fig. $4 \mathrm{~b}$.

\section{Cell-wall extension}

Plant CWs have the remarkable property of combining extreme tensile strength with extensibility, which plays principal roles in the control of growth and development of plants. A simplified model of the potential effects of drought and $\mathrm{Al}$ on cell-wall extension is shown in Fig. 5.
The progressive decrease of growth towards the basal region of root tips in the elongation zone under water deficit has been explained by reduced $\mathrm{CW}$ extensibility (Fan et al. 2006). Under Al stress, Al strongly binds to the negative charges provided by the carboxylic groups of galacturonic acids of the pectins (Blamey et al. 1990; Chang et al. 1999) and to hemicellulose (Yang et al. 2011a). There is little doubt that the high affinity of Al to the pectic matrix and hemicellulose will substantially affect the chemical and mechanical properties of the $\mathrm{CW}$, and this $\mathrm{Al}$-apoplast interaction has been proposed as the main cause of Al-induced inhibition of root elongation (Horst et al. 2010). Two possibilities have been suggested: i) Al rapidly and irreversibly displace $\mathrm{Ca}^{2+}$ at the site of $\mathrm{Ca}^{2+}$-pectate cross-linkages, which plays a key role in controlling CW extensibility and thus cell elongation and development (Boyer 2009). The formation of cross-linkages by $\mathrm{Al}$ may rigidify the $\mathrm{CW}$, thereby preventing wall loosening which is a prerequisite for cell elongation. ii) Strong binding of $\mathrm{Al}$ to the pectic matrix may prevent $\mathrm{CW}$ extension physically and/or physiologically by decreasing the effectiveness of CWloosening enzymes (Wehr et al. 2004). In addition, Tabuchi and Matsumoto (2001) suggested that the Aldecreased mechanical extensibility of the $\mathrm{CW}$ in wheat roots could be attributed to an increase in ferulic and diferulic acids, which crosslink CW structural components and thus strengthen the CW (Brett and Waldron 1996). The water deficit-enhanced production of phenols in the root tips was made responsible for the progressive growth cessation towards the basal region in the elongation-zone of maize (Fan and Neumann 2004) and soybean roots (Yamaguchi et al. 2010).

The mechanisms involved in regulating $\mathrm{CW}$ extension capacity and hence root growth has been intensively investigated and frequently reviewed (Cosgrove 2005; Rose et al. 2004; Sharp et al. 2004; Wu and Cosgrove 2000). The extensibility of the CW is controlled by its structure as well as the activity of CWmodifying proteins such as expansins, XTHs and glucanases (Bray 2004; Wu and Cosgrove 2000). Under drought in Al-toxic acid soils and PEG-induced osmotic stress in hydroponics, the expression of both $X T H s$ and $B E G$ genes in the root tips of common bean were suppressed by both water deficit and $\mathrm{Al}$ stress leading to inhibition of root elongation (Yang et al. 2011c, 2012). Spatial pattern analysis of XTH by the detection of xyloglucan endotransglucosylase (XET) action in Arabidopsis and tabacco (Nicotiana tabacum L.) root 


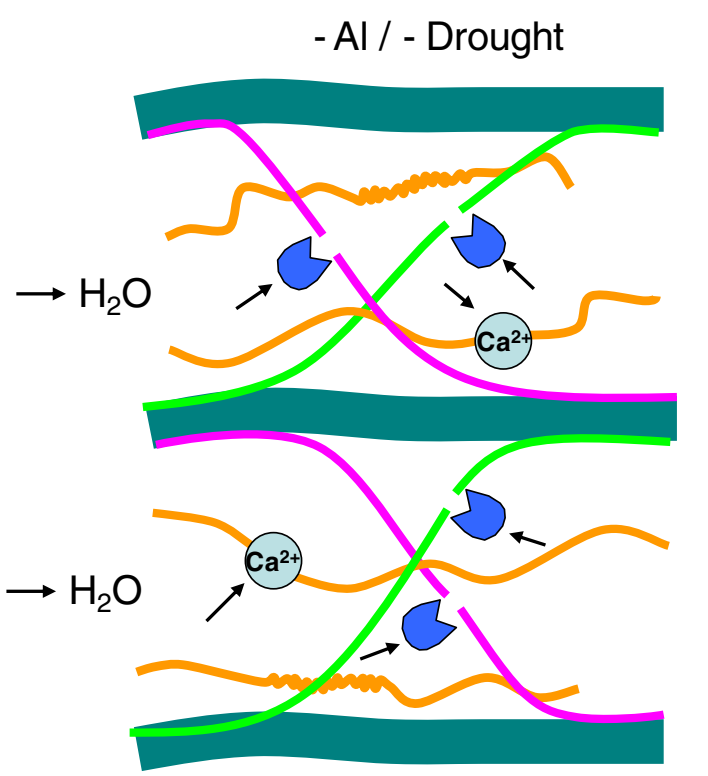

$+\mathrm{Al} /$ + Drought

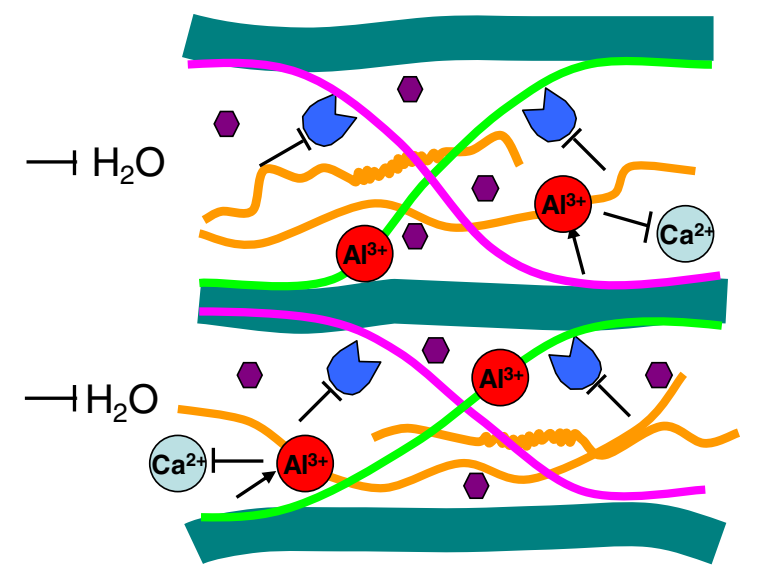

Cellulose

Fig. 5 A simplified model representing the effect of Al or drought stress on cell-wall extention. On the left, cell-wall extension without the stresses is shown: $\mathrm{H}_{2} \mathrm{O}$ penetration into the cell wall and the symplast allows the build-up of osmotic pressure and high activity of the cell-wall modification-enzyme XET thus allowing cell-wall extention. On the right, the effect of drought or Al on cell-wall extension is shown: reduced

tips, showed that XTH in the cortex and epidermis of the elongation zone is primarily involved in wall loosening for root elongation (Vissenberg et al. 2000).

Phytohormone signal network

The growth and development of plants under environmental stresses is mediated by phytohormones such as ABA, auxin and CK, gibberellin (GA), ethylene and jasmonic acid (JA) (Wolters and Jürgens 2009). Based on the studies with common bean (Yang et al. 2012), the crosstalk between phytohormons in response to drought and combined drought/Al stresses affecting root growth is schematically shown in Fig. 6. Among the phytohormones, it is well known that ABA is produced under water-deficit conditions and plays an important role in the response of plants to drought. In the root tips, the accumulation of ABA increases towards the root apex (Saab et al. 1992) and is required for the maintenance of maize primary-root elongation hydration of the cell wall and Al-inhibited XET activity, and strong binding of $\mathrm{Al}$ to pectins and xyloglucans reduce cell-wall extensibility. Al and drought-enhanced crosslinking of cell-wall structures by phenolics further reduce extensibility. XET: xyloglucan endotransglucosylase. Based on Yang et al. (2010, 2011c, 2012)

at low water potentials (Sharp 2002; Sharp et al. 2004; Yamaguchi and Sharp 2010). Zeaxanthin epoxidase (ZEP), 9-cis-epoxycarotenoid dioxygenase (NCED) and abscisic aldehyde oxidase (AAO) are the critical enzymes involved in the biosynthesis of ABA (Seo and Koshiba 2002). The expression of the genes encoding these enzymes is induced by drought in different plant species (Audran et al. 1998; Chernys and Zeevaart 2000; Iuchi et al. 2000; Qin and Zeevaart 1999; Seo et al. 2000; Seiler et al. 2011; Thompson et al. 2000; Yang et al. 2012) and is indicative of improved drought resistance (Iuchi et al. 2001; Qin and Zeevaart 2002).

Several hydroponic studies have shown that $\mathrm{Al}$ induces ABA production in the root tips of soybean (Hou et al. 2010; Shen et al. 2004) and barley (Kasai et al. 1993), which was supposed to regulate $\mathrm{Al}$ resistance mechanisms (Hou et al. 2010; Shen et al. 2004). However, growing common bean in an acid Al-toxic soil slightly but significantly reduced the ABA accumulation in the 


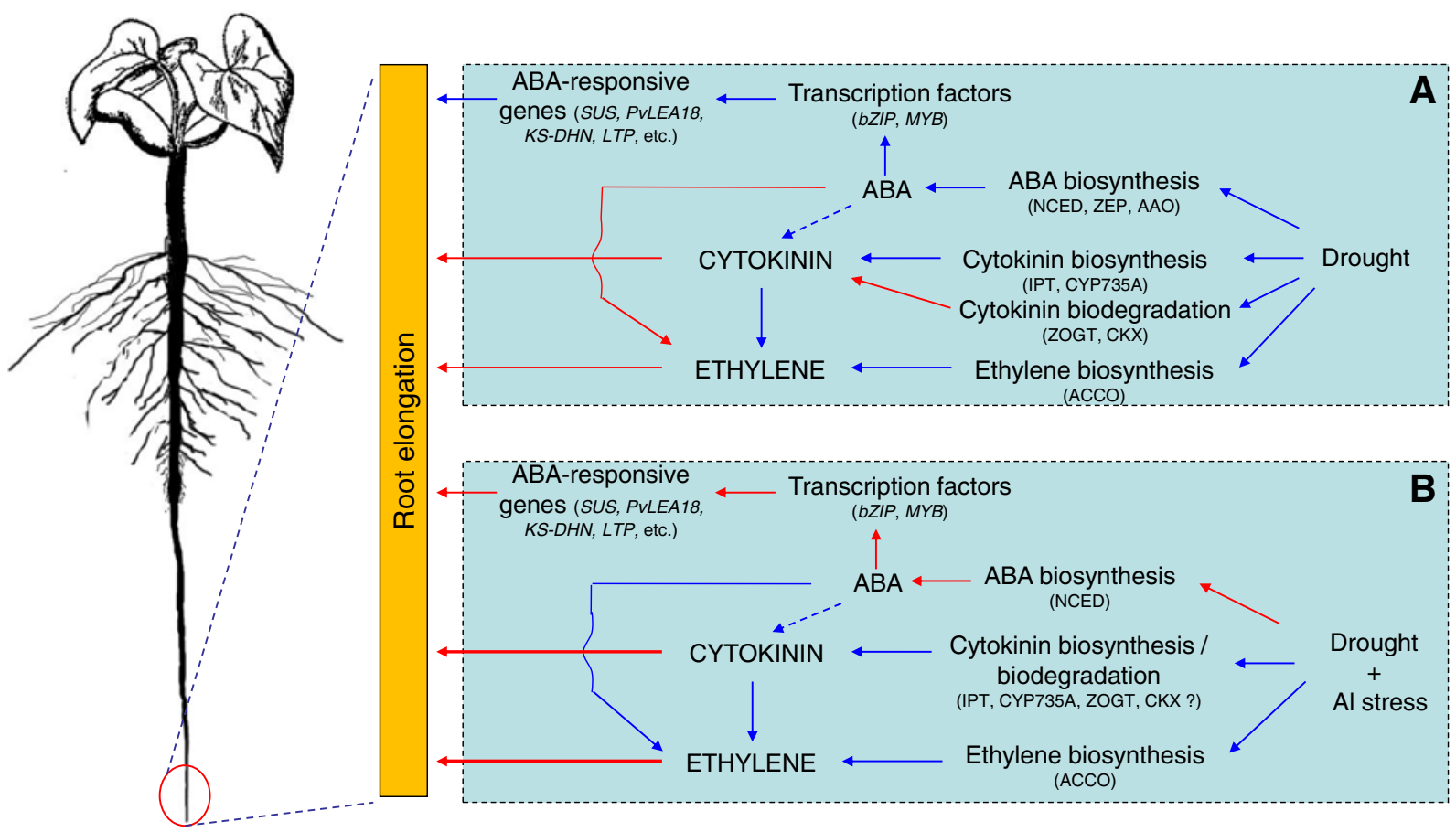

Fig. 6 Schematic representation of the potential regulatory mechanisms involved in acclimation to drought of root apices of common bean and how Al stress interferes with this acclimation. In a: Sole drought stress increase ABA, ethylene and cytokinin $(\mathrm{CK})$ concentrations in root tips by the regulation of biosynthetic or degrading enzymes such as NCED, ZEP, AAO (ABA biosynthesis), IPT, CYP735A, ZOGT, CKX (CK biosynthesis and biodegradation) and ACCO (ethylene biosynthesis). The excess accumulation of $\mathrm{CK}$ and ethylene inhibit root elongation, whereas the drought-stimulated ABA accumulation maintains root elongation in the apical elongation zone by upregulating the expression of ABA-dependent genes. The blue and red arrows indicate up- and down-regulated changes, respectively. In b: In comparision with the sole drought effect,

root tips and had no effect on the expression of genes involved in ABA biosynthesis (Yang et al. 2012). In spite of this, under combined $\mathrm{Al}$ and drought-stress conditions Al suppressed the drought-stimulated ABA production as well as the expression of the NCED gene in the root tips. Therefore, the suppression of ABA production in the root tips by $\mathrm{Al}$ reduced the drought resistance of the roots. The critical role of $\mathrm{ABA}$ in drought resistance depends on its involvement in the regulation of drought-induced genes (Bray 1997, 2002). The transcription factors bZIP and MYB are responsible for the down-stream regulation of ABA-dependent genes (Shinozaki and Yamaguchi-Shinozaki 1997, 2007). The consistency of the expression of bZIP, $M Y B$, and ABA-dependent genes such as SUS (sucrose additional $\mathrm{Al}$ exposure leads to an aggravated inhibition of root elongation by the suppression of ABA-dependent droughtinduced gene regulation and by further promoting $\mathrm{CK}$ and related ethylene synthesis. The blue and red arrows in $\mathbf{b}$ indicate the enhanced and inhibited changes in comparision with the sole drought-induced changes in a, their thickness represents the magnitude of the changes. IPT, adenosinephosphate isopentenyl-transferase; CYP735A, cytochrome P450 monooxygenase 735A; CKX, CK oxidase/dehydrogenase; ZOGT, zeatin-O-glucosyltransferase; ACCO, 1-aminocyclopropane-1carboxylic acid oxidase; ZEP, zeaxanthin epoxidase; NCED, 9-cis-epoxycarotenoid dioxygenase; AAO, abscisic aldehyde oxidase. Based on Yang et al. (2012)

synthase), $P v L E A 18$ (late embryogenesis abundant protein), $K S-D H N($ KS-type dehydrin) and $L T P$ (lipid-transfer protein) (Brocard-Gifford et al. 2004; Hundertmark and Hincha 2008; Orellana et al. 2010) with the change of ABA accumulation and the expression of NCED in the root tips of common bean under $\mathrm{Al}$ and drought stress, suggest that the Al toxicity-enhanced drought sensitivity of the root apex is due to the impact of the gene regulatory network involved in ABA signal transduction (Yang et al. 2012).

In addition to ABA, ethylene is implicated in the inhibition of root elongation (Le et al. 2001). The results by Yang et al. (2012) indicated that the Alaggravated drought-induced inhibition of root elongation in common bean may partly be due to an 
enhanced expression of the ethylene biosynthesis gene $A C C O$ (see Fig. 3d) and thus ethylene production in root tips.

The interplay of phytohormones plays a crucial role in the regulation of root growth and has been widely studied. For example, several studies have demonstrated that ethylene regulates root growth mainly through effects on auxin biosynthesis and transport-dependent auxin distribution (Růžička et al. 2007; Stepanova et al. 2007; Swarup et al. 2007; Sun et al. 2010). The CKauxin interaction is fundamental in controlling root development (reviewed by Moubayidin et al. 2009). It is well known that CKs may also strongly inhibit root growth (Werner et al. 2001). Under water-deficit conditions, $\mathrm{ABA}$ can suppress ethylene production, and the maintenance of root elongation requires increased $\mathrm{ABA}$ levels to prevent excess ethylene production (LeNoble et al. 2004; Sharp et al. 2000; Spollen et al. 2000; Sharp 2002). Ding et al. (2008) found that ABA could suppress $\mathrm{CK}$ activation of cell division in the roots of Medicago truncatula Gaertn.. Takei et al. (2004) observed that ABA treatment highly reduced the expression of the CK biosynthesis genes CYP735A1 and CYP735A2 in the roots of Arabidopsis. Cytokinin stimulated ethylene biosynthesis (Chae et al. 2003) and ethylene mediated the CK-induced inhibition of root elongation as observed in pea (Pisum sativum L.) (Bertell and Eliasson 1992), Arabidopsis (Cary et al. 1995; Růžička et al. 2009) and common bean (Massot et al. 2002). However, the analysis of the IAA content in the root tips of common bean under $\mathrm{Al}$ and drought stress conditions by Yang et al. (2012) did not support an involvement of the auxin-dependent regulatory signaling network in the Al-drought interaction on root growth. The reason for the aggravation of the inhibition of root elongation by drought through $\mathrm{Al}$ (Yang et al. 2012) may partly be due to reduced ABA levels, promoted CK production (Fig. 7) and subsequently stimulated synthesis of ethylene in the root tips of common bean as depicted in Fig. 6.

\section{Interaction of aluminium-drought stresses on crop yield}

Crop yield is the result of a multitude of developmental, physiological and biochemical processes and their interactions at any level of plant organization and any level of biological scale that are under genetic control.

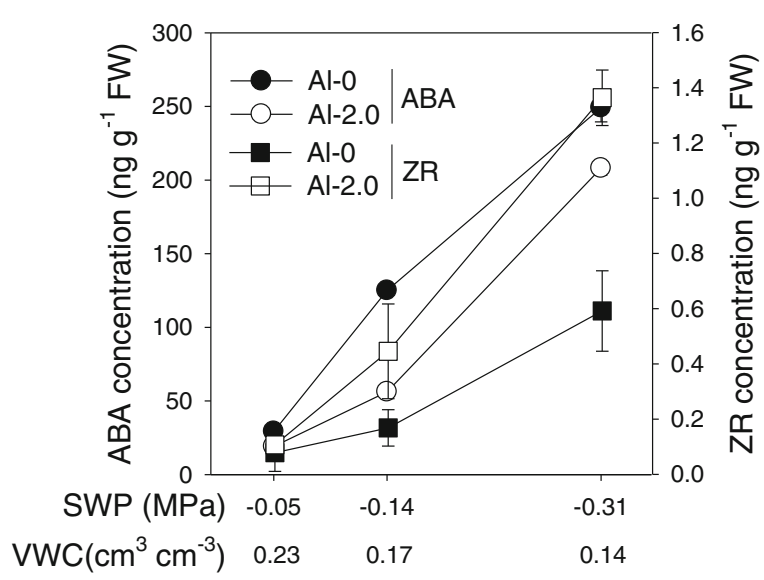

Fig. 7 Abscisic acid (ABA) and zeatin riboside (ZR) concentrations in the 1-cm root tips of common bean genotype VAX-1 as affected by soil moisture and $\mathrm{Al}$ supply $\left(\mathrm{g} \mathrm{AlCl} \mathrm{Al}_{3} \cdot 6 \mathrm{H}_{2} \mathrm{O} \mathrm{kg}\right.$ soil). Two-day-old seedlings were grown in soil for $24 \mathrm{~h}$. Bars represents means $\pm \mathrm{SD}, n=3$. SWP: soil-water potential; VWC: volumetric water content. Compiled from Yang et al. (2012)

The sum total is integrated toward a final effect on yield (Blum 2010). Knowledge on the interaction of Al-drought stresses on crop yield is limited. The most direct method of evaluating the interaction of $\mathrm{Al}$ and drought stresses is by measuring economic yield (grain or forage) under field conditions. Field evaluation for soil acidity and Al toxicity is normally conducted in two duplicate tests: one in an unamended, naturally acid plot, and the other in a lime-amended plot. The data are reported as the ratio of grain or forage yield in the unamended plot to that in the lime-amended plot to adjust for differences in yield potential without soil-acidity stress. This methodology was used by a number of researchers to screen crop and forage germplasm for their adaptation to acid soils (Baier et al. 1995; Carver and Ownby 1995; Johnson et al. 1997; Marschner 1995; Rao et al. 1993, 1998, 2004, 2011; Rao 2001; Tang et al. 2003c; The et al. 2001). Field studies conducted on an acid soil in Cameroon by The et al. $(2001,2006,2012)$ indicated that yield of the soil acidity-tolerant maize cultivar ATP-SR-Y was up to $60 \%$ higher than that of the soil acidity-sensitive cultivar Tuxpeno-Sequia. Among the maize germplasm tested, there was a large variability in grain yield on non-corrected acid as well as on corrected non-acid soil. One of the phenotypic plant characteristics that best correlated with the adaptation of the genotypes to soil acidity was seminal root length (The et al. 2001). 
It has been reported that $\mathrm{Al}$ toxicity restricts the yield of many crops particularly in regions with acid subsoils throughout the world (Sumner et al. 1986). Aluminium toxicity decreases drought resistance and the use of subsoil nutrients (Wang et al. 2006). Deleterious effects of subsoil soil-acidity on crop yield will thus be influenced by the extent to which a plant depends on the subsoil for supply of water and nutrients, especially when the topsoil dries out (Jozefaciuk and Szatanik-Kloc 2001; Stodart et al. 2007; Tang et al. 2001, 2003a, b). Sorghum (Sorghum bicolor (L.) Moench) growing on acid soils yields less than its potential because of the poorly developed roots that cause reduced nutrient and water uptake (Meda and Furlani 2005; Bernel and Clark 1998). During the rainy season the soil moisture in the topsoil can sufficiently sustain shoot growth, while in the dry season the low rainfall will force the roots to explore deeper subsoil for water. The growth of roots grown in the acidic subsoil will then subsequently suffer from Al toxicity and the Al-impeded root growth will further restrict the exploitation of deeper subsoil for water.

Similar to acid soil stress, yield under drought stress with reference to yield under non-stressed conditions, has normally been employed as the primary phenotypic selection criterion in improving drought resistance in crops (Blum 2010). Farmers frequently request early maturing cultivars in environments where the growing season is limited by water availability. However, early maturity also has disadvantages including limited yield potential. Recent breeding efforts for improving drought resistance in common bean resulted in small seeded Mesoamerican lines (coded as SER and SEN) with up to $36 \%$ greater yield per day in unfavorable environments (Beebe et al. 2008). The lesson learned from this work was that shoot biomass and yield should be selected for while retaining the ability to partition greater proportion of photosynthates from vegetative plant structures to grain (Rao et al. 2009; Beebe 2012).

\section{Crop-yield improvement-strategies for adaption to combined aluminium toxicity and drought stress}

Crop yield improvement for adaptation to acid soils with seasonal drought stress at the molecular and physiological level is very complex and challenging.
The simplest approach to breeding for adaptation to combined $\mathrm{Al}$ toxicity and drought stress is to select for grain or forage yield which are the integrating traits, and to carry out the selection in a managed stress environment. A possible breeding strategy for developing crops for superior adaptation to combined stress conditions of soil acidity and drought could involve screening germplasm under well watered and droughtstressed conditions on an acid soil and make selections based on superior performance (yield) under both conditions. It is widely recognized by breeders and agronomists that field screening is highly variable and complex. Thus there is a need to select for secondary phenotypic traits for both $\mathrm{Al}$ and drought resistance which can be easily identified using screening methods at laboratory, greenhouse and field level. These phenotypic traits should be linked to molecular genotypic traits. Significant progress in crop improvement can be achieved by the use of screening methods where the stresses are carefully managed and by choosing parents of crosses with desirable shoot and root traits for genetic recombination to improve yield under individual and combined stress factors (Beebe et al. 2008, 2009).

A number of shoot and root traits contribute to improved drought adaptation (Blum 2010). The root traits maximise water uptake and the shoot traits optimise the use of absorbed water for producing grain during drought stress. In sorghum, the panicle weight of the first filial generation (F1) of hybridisation between inbred P1 (drought-tolerant) and P2 (Al-resistant) was greater than either P1 or P2 under both stress and non-stress conditions, suggesting that multiple stress resistance can increase sorghum productivity (Okiyo et al. 2010). Using different bean species, Butare et al. (2011) found that Al partially ameliorated the negative effects of water stress in Al-resistant Phaseolus coccineus L. genotypes. This response was strongly in contrast with Al-sensitive Phaseolus acutifolius and the Mesoamerican common bean genotypes, where combined stress led to a more severe inhibition of root development. These observations were consistent with the results obtained by Yang et al. (2012). Thus, it appears promising to use interspecific crosses with Phaseolus coccineus to improve combined drought and $\mathrm{Al}$ resistance of common bean (Butare et al. 2012).

Both Al toxicity and water stress should be considered in breeding for better adaptation to acid soils. 
Amelioration of these constraints in the topsoil can be achieved by liming, fertilization and irrigation. For example, in eastern regions of the Western Australian wheat belt, Porter and Wilson (1984) found that the application of lime to the acidic subsurface soil layers increased wheat yields by $69 \%$ and $175 \%$ at two sites. Using the computer model APSIM (Agricultural Production Systems Simulator), Tang et al. (2003a) concluded that liming and nitrogen application increased yields of wheat in all rainfall zones, but the yield increments were much greater in the high than the low rainfall zones, and that improved yields were correlated with increased rooting depth and associated decreased nitrate-N leaching. Doss and Lund (1975) reported that the reductions in the yield of cotton resulting from shallow root systems on acid sub-soils can be overcome by frequent irrigation of the surface soil, but rooting depth and pattern were not affected by irrigation. The management of plant nutrients is very helpful to alleviate the adverse effects of drought (Waraich et al. 2011). However, the soil amendments are neither economic options for poor farmers nor effective strategies for alleviating the subsoil acidity stress. Tang et al. (2003a, b, c) have found that the yield benefits arising from growing Al-resistant wheat were greater than those from ameliorating soil acidity by liming. Therefore, screening of crop germplasm and developing appropriate varieties with high resistance against combined $\mathrm{Al}$ toxicity and drought could lead to higher and more stable crop yields, particularly in the smallholder farms of the tropics (Beebe et al. 2009; Beebe 2012).

In two near-isogenic wheat genotypes differing in $\mathrm{Al}$ resistance, Tang et al. (2001) found that the Al-resistant genotype ET8 can produce more than five times the root length of Al-sensitive genotype ES8 in the acidic subsoil. The genotypic variation in growth and yield of wheat grown under subsoil acidity results from the difference in root proliferation into the subsoil and hence in the exploitation of water and nutrients in the acidic subsoil layer (Tang et al. 2002). The genotypic variation in response to liming appears to result from the difference in the sensitivity of root proliferation to low pH and high Al (Tang et al. 2003b). Wasson et al. (2012) proposed that wheat varieties with a deeper root system, a redistribution of branch root density from the surface to depth, and with greater radial hydraulic conductivity at depth would have higher yields in those rainfed systems where crops rely on soil moisture from deeper layers for grain filling. The evaluation of the trait and development of selection processes for root-system traits (deep, highly branched roots) combining laboratory and field phenotypic screening in a breeding programme have been thoroughly reviewed by these authors.

Therefore, deep rooting is particularly important for the improvement of yield in the breeding for adaptation to Al toxicity and drought stress (Sponchiado et al. 1989). Combining functional genomics with traditional breeding (Ishitani et al. 2004; Manavalan et al. 2009; Mir et al. 2012) will contribute greatly to bridging the gap between phenotype and genotype in the context of breeding for complex traits such as adaptation to abiotic stresses.

\section{Conclusions and future perspectives}

Drought can be exacerbated by subsoil Al toxicity, which reduces root elongation and restricts the plant roots to explore the acidic subsoil to absorb water, and thus diminishes the ability to avoid drought stress. Little is known about the interaction of Al toxicity and low soil moisture stress at the root-tip level. In common bean, drought/osmotic stress reduced $\mathrm{Al}$ uptake and $\mathrm{Al}$ toxicity. However, Al toxicity enhanced the drought-induced inhibition of root elongation. The physiological and molecular evidence suggests that the reason for this Alaggravated drought sensitivity of root apices is a disturbance of the gene regulatory network involved in ABA signal transduction and cross-talk with other phytohormones such as CKs and ethylene that are necessary for maintaining root growth under drought. These suggestions need to be substantiated through further studies in the future focusing on the following aspects: i) Understanding the role of genes related to CW modification in the interaction of $\mathrm{Al}$ toxicity and drought stress; ii) Clarification of the cross-talk of phytohormones in the Al-regulated drought-inhibited root elongation necessary to better understand the internal regulatory mechanism of root growth under individual and combined stresses using reverse genetic approaches; iii) Comparative analysis of the relationship between $\mathrm{Al}$ toxicity and drought stress in monocots and dicots which appears attractive given the different structural components of the $\mathrm{CW}$.

Effects of $\mathrm{Al}$ on shoot growth are mostly secondary effects that are induced by $\mathrm{Al}$ affecting root growth and function, while under drought stress root growth may even be promoted. There is limited knowledge on 
the interaction of $\mathrm{Al}$ and drought stresses on crop yield. Present knowledge suggests that Al toxicity decreases drought resistance primarily by reducing the use of subsoil water and nutrients, and crops yield less under combined stresses.

Breeding for drought resistance must be combined with resistance to $\mathrm{Al}$, to assure that drought resistance is expressed adequately in crops grown on soils with acid Al-toxic subsoils. A possible breeding strategy could involve screening germplasm under well watered and drought-stressed conditions on an acid soil and make selections based on superior performance (yield) under both conditions. Since field screening is highly variable and complex secondary phenotypic traits for both $\mathrm{Al}$ and drought resistance which can be easily identified using screening methods at laboratory, greenhouse and field level need to be linked to molecular genotypic traits.

An integrated improvement of resistance against both stress factors is likely to be more productive than considering them in isolation. It appears necessary to identify molecular markers QTLs (quantitative trait loci) for adaptation to combined $\mathrm{Al}$ and drought stresses with focus on genes controlling root growth increasing the efficiency of traditional breeding approaches. The challenge is to identify QTLs of major effects that are independent of the particular genetic background and clone the genes in the QTL. The ability of next generation sequencing and advanced metabolic profiling to co-sequence or coscreen a large number of F2 or RILs coupled with statistical linkage analysis could improve the efficiency of molecular breeding for improved adaptation to combined stresses of $\mathrm{Al}$ and drought.

Acknowledgments The research work on common bean was supported by a restricted core project fromthe Bundesministerium für Wirtschaftliche Zusammenarbeit / Gesellschaft für Technische Zusammenarbeit (BMZ/GTZ) (No. 05.7860.9001.00) granted to the International Center for Tropical Agriculture (CIAT).

\section{References}

Aftab T, Khan MMA, Idrees M, Naeem M, Moinuddin (2010) Effects of aluminum exposures on growth, photosynthetic efficiency, lipid peroxidation, antioxidant enzymes and artimisinin content of Artemisia annua L. J Phytol 2:23-37
Atkinson NJ, Urwin PE (2012) The interaction of plant biotic and abiotic stresses: from genes to the field. J Exp Bot 63:3523-3544

Audran C, Borel C, Frey A, Sotta B, Meyer C, Simonneau T, Marion-Poll A (1998) Expression studies of the zeaxanthin epoxidase gene in Nicotiana plumbaginifolia. Plant Physiol 118:1021-1028

Baier AC, Somers DJ, Gustafson JP (1995) Aluminum tolerance in wheat: correlating hydroponic evaluation with field and soil performances. Plant Breed 114:291-296

Barceló J, Poschenrieder CH, Vdzquez MD, Gunsé B (1996) Aluminium phytotoxicity: a challenge for plant scientists. Fert Res 43:217-226

Baron-Epel O, Gharyal PK, Schindler M (1988) Pectins as mediators of wall porosity in soybean cells. Planta 175:389-395

Bartsch N (1987) Responses of root systems of young Pinussylvestris and Piceaabies plants to water deficits and soil acidity. Can J For Res 17:805-812

Bauchot AD, Hallett IC, Redgwell RJ, Lallu N (1999) Cell wall properties of kiwifruit affected by low temperature breakdown. Postharvest Biol Technol 16:245-255

Beebe SE (2012) Common bean breeding in the tropics. Plant Breed Rev 36:357-426

Beebe S, Rao IM, Cajiao C, Grajales M (2008) Selection for drought resistance in common bean also improves yield in phosphorus limited and favorable environments. Crop Sci 48:582-592

Beebe S, Rao IM, Blair MW, Butare L (2009) Breeding for abiotic stress tolerance in common bean: present and future challenges. SABRAO J Breed Genet 41: special supplement

Beebe SE, Rao IM, Blair MW, Acosta-Gallegos JA (2010) Phenotyping common beans for adaptation to drought. In: Ribaut JM and Monneveux P (eds) Drought phenotyping in crops: from theory to practice. Generation challenge program special issue on phenotyping. Generation Challenge Program of CGIAR, Mexico City, Mexico, pp 311-334

Beebe S, Ramirez J, Jarvis A, Rao IM, Mosquera G, Bueno JM, Blair M (2011) Genetic improvement of common beans and the challenges of climate change. In: Yadav SS, Redden RJ, Hatfield JL, Lotze-Campen H, Hall AE (eds) Crop adaptation to climate change, 1 st edn. Wiley, New York, pp 356-369

Bengough AG, McKenzie BM, Hallett PD, Valentine TA (2011) Root elongation, water stress, and mechanical impedance: a review of limiting stresses and beneficial root tip traits. $\mathrm{J}$ Exp Bot 62:59-68

Bernel JH, Clark RB (1998) Growth traits among sorghum genotypes in response to $\mathrm{Al}^{3+}$. J Plant Nutr 21:297-305

Bertell G, Eliasson L (1992) Cytokinin effects on root growth and possible interactions with ethylene and indole-3-acetic acid. Physiol Plant 84:255-261

Blamey FPC, Edmeades DC, Wheeler DM (1990) Role of root cation-exchange capacity in differential aluminium tolerance of Lotus species. J Plant Nutr 13:729-744

Blamey FPC, Asher CJ, Edwards DG, Kerven GL (1993) In vitro evidence of aluminium effects on solution movement through root cell walls. J Plant Nutr 16:555-562

Blum A (2010) Plant breeding for water-limited environments. Springer, New York, p 272

Bota J, Medrano H, Flexas J (2004) Is photosynthesis limited by decreased Rubisco acivity and RuBP content under progressive water stress? New Phytol 162:671-681 
Boyer JS (2009) Cell wall biosynthesis and the molecular mechanism of plant enlargement. Funct Plant Biol 36:383-394

Bray EA (1997) Plant responses to water deficit. Trends Plant Sci 2:48-54

Bray EA (2002) Abscisic acid regulation of gene expression during water deficit stress in the era of the Arabidopsis genome. Plant Cell Environ 25:153-161

Bray EA (2004) Genes commonly regulated by water-deficit stress in Arabidopsis thaliana. J Exp Bot 55:2331-2341

Brett C, Waldron K (1996) Physiology and biochemistry of the plant cell wall. Chapman and Hall, London

Brocard-Gifford I, Lynch TJ, Garcia ME, Malhotra B, Finkelstein RR (2004) The Arabidopsis thaliana abscisic acidinsentive8locus encodes a novel protein mediating abscisic acid and sugar responses essential for growth. Plant Cell 16:406-421

Brummel DA (2006) Cell wall disassembly in ripening fruit. Funct Plant Biol 33:103-119

Butare L, Rao I, Lepoivre P, Polania J, Cajiao C, Cuasquer J, Beebe S (2011) New genetic sources of resistance in the genus Phaseolus to individual and combined stress factors of aluminium toxicity and progressive soil drying. Euphytica 185:385-404

Butare L, Rao IM, Lepoivre P, Cajiao C, Polania J, Cuasquer JB, Beebe S (2012) Phenotypic evaluation of interspecific Recombinant Inbred Lines (RILs) of Phaseolus species for aluminum resistance and shoot and root growth response to aluminum-toxic acid soil. Euphytica 186:715-730

Carpita NC, Gibeaut DM (1993) Structural models of primary cell walls in flowering plants: consistency of molecular structure with the physical properties of the walls during growth. Plant J3:1-30

Carpita N, Sabularse D, Montezinos D, Delmer DP (1979) Determination of the pore size of cell walls of living plant cells. Science 205:1144-1147

Carver BF, Ownby JD (1995) Acid soil tolerance in wheat. Adv Agron 54:117-173

Cary AJ, Liu W, Howell SH (1995) Cytokinin action is coupled to ethylene in its effects on the inhibition of root and hypocotyl elongation in Arabidopsis thaliana seedlings. Plant Physiol 107:1075-1082

Chae HS, Faure F, Kieber JJ (2003) The eto1, eto2, and eto3 mutations and cytokinin treatment increase ethylene biosynthesis in Arabidopsis by increasing the stability of ACS protein. Plant Cell 15:545-559

Chang YC, Yamamoto Y, Matsumoto H (1999) Accumulation of aluminium in the cell wall pectin in cultured tobacco (Nicotiana tabacum L.) cells treated with a combination of aluminium and iron. Plant Cell Environ 22:1009-1017

Chaves MM, Oliveira MM (2004) Mechanisms underlying plant resilience to water deficits: prospects for water-saving agriculture. J Exp Bot 55:2365-2384

Chaves MM, Maroco JP, Pereira JS (2003) Understanding plant responses to drought - from genes to the whole plant. Funct Plant Biol 30:239-264

Chen LS (2006) Physiological responses and tolerance of shoot to aluminum toxicity. J Plant Physiol Mol Biol 32:143-155
Chen J, Sucoff EI, Stadelmann EJ (1991) Aluminum and temperature alteration of cell membrane permeability of Quercus rubra. Plant Physiol 96:644-649

Chernys J, Zeevaart JAD (2000) Characterization of the 9-cisepoxycarotenoid dioxygenase gene family and the regulation of abscisic acid biosynthesis in avocado. Plant Physiol 124:343-353

Chesson A, Gardner PT, Wood TJ (1997) Cell wall porosity and available surface area of wheat straw and wheat grain fractions. J Sci Food Agric 75:289-295

Cosgrove DJ (1997) Assembly and enlargement of the primary cell wall in plants. Annu Rev Cell Dev Biol 13:171-201

Cosgrove DJ (2005) Growth of the plant cell wall. Nat Rev Mol Cell Biol 6:850-861

Davies WJ, Kudoyarova G, Hartung W (2005) Long-distance ABA signaling and its relation to other signaling pathways in the detection of soil drying and the mediation of the plant's response to drought. J Plant Growth Regul 24:285-295

Delhaize E, Ryan PR (1995) Aluminum toxicity and tolerance in plants. Plant Physiol 107:315-321

Ding Y, Kalo P, Yendrek C, Sun J, Liang Y, Marsh JF, Harris JM, Oldroyd GE (2008) Abscisic acid coordinates nod factor and cytokinin signaling during the regulation of nodulation in Medicago truncatula. Plant Cell 20:26812695

Dodd IC (2005) Root-to-shoot signalling: assessing the roles of 'up' in the up and down world of long-distance signalling in planta. Plant Soil 274:251-270

Doss BD, Lund ZF (1975) Subsurface soil pH effects on growth and yield of cotton. Agron J 67:193-196

Eticha D, Staß A, Horst WJ (2005) Cell-wall pectin and its degree of methylation in the maize root-apex: significance for genotypic differences in aluminium resistance. Plant Cell Environ 28:1410-1420

Eticha D, Zahn M, Bremer M, Yang Z, Rangel AF, Rao IM, Horst WJ (2010) Transcriptomic analysis reveals differential gene expression in response to aluminium in common bean (Phaseolus vulgaris) genotypes. Ann Bot (London) 105:1119-1128

Fan S, Blake TJ (1997) Comparison of polyethylene glycol 3350 induced osmotic stress and soil drying for drought simulation in three woody species. Trees 11:342-348

Fan L, Neumann PM (2004) The spatially variable inhibition by water deficit of maize root growth correlates with altered profiles of proton flux and cell wall $\mathrm{pH}$. Plant Physiol 135:2291-2300

Fan L, Linker R, Gepstein S, Tanimoto E, Yamamoto R, Neumann PM (2006) Progressive inhibition by water deficit of cell wall extensibility and growth along the elongation zone of maize roots is related to increased lignin metabolism and progressive stelar accumulation of wall phenolics. Plant Physiol 140:603-612

Fleischer A, O’Neill MA, Ehwald R (1999) The pore size of non-graminaceous plant cell walls is rapidly decreased by borate ester cross-linking of the pectic polysaccharide rhamnogalacturonan II. Plant Physiol 121:829-838

Foy CD (1974) Effects of aluminum on plant growth. In: Carson EW (ed) The plant root and its environment. University Press of Virginia, Charlottesville, pp 601-642

Foy CD (1984) Physiological effects of hydrogen, aluminum, and manganese toxicities in acid soil. In: Adams F (ed) Soil 
acidity and liming, 2nd edn. American Society of Agronomy, Inc, Madison, pp 57-97

Foy CD, Sadeghi AM, Ritchie JC, Krizek DT, Davis JR, Kemper WD (1999) Aluminum toxicity and high bulk density: role in limiting shoot and root growth of selected aluminum indicator plants and eastern gamagrass in an acid soil. J Plant Nutr 22:1551-1566

Furukawa J, Yamaji N, Wang H, Mitani N, Murata Y, Sato K, Katsuhara M, Takeda K, Ma JF (2007) An aluminumactivated citrate transporter in barley. Plant Cell Physiol 48:1081-1091

George E, Horst WJ, Neumann E (2012) Adaptation of plants to adverse chemical soil conditions. In: Marschner P (ed) Marschner's mineral nutrition of higher plants, 3rd edn. Elsevier, Amsterdam, pp 409-472

Goldman IL, JrTE C, Patterson RP (1989) A detrimental interaction of subsoil aluminum and drought stress on the leaf water status of soybean. Agron J 81:461-463

Graham CJ (2002) Nonstructural carbohydrate and prunasin composition of peach seedlings fertilized with different nitrogen source and aluminum. Sci Hortic 94:21-32

Gunsé B, Poschenrieder C, Barceló J (1997) Water transport properties of roots and root cortical cells in proton- and Alstressed maize varieties. Plant Physiol 113:595-602

Hairiah K, Noordwijk M, Setijono S (1995) Tolerance and avoidance of Al toxicity by Mucuna pruriens var. utilis at different levels of P supply. Plant Soil 171:77-81

Hasenstein KH, Evans ML (1988) Effects of cations on hormone transport in primary roots of Zea mays. Plant Physiol 86:890-894

Hohl M, Schopfer P (1991) Water relations of growing maize coleoptiles: comparison between mannitol and polyethylene glycol 6000 as external osmotica for adjusting turgor pressure. Plant Physiol 95:716-722

Horst WJ, Wagner A, Marschner H (1982) Mucilage protects root meristems from aluminium injury. Z Pflanzenphysiol 105:435-444

Horst WJ, Klotz F, Szulkiewicz P (1990) Mechanical impedance increases aluminium tolerance of soybean (Glycine max) roots. Plant Soil 124:227-231

Horst WJ, Asher CJ, Cakmak J, Szulkiewicz P, Wissemeier AH (1992) Short-term responses of soybean roots to aluminium. J Plant Physiol 140:174-178

Horst WJ, Wang Y, Eticha D (2010) The role of the root apoplast in aluminium-induced inhibition of root elongation and in aluminium resistance of plants: a review. Ann Bot 106:185-197

Hou N, You J, Pang J, Xu M, Chen G, Yang ZM (2010) The accumulation and transport of abscisic acid in soybean (Glycine $\max$ L.) under aluminum stress. Plant Soil 330:127-137

Hundertmark M, Hincha DK (2008) LEA (late embryogenesis abundant) proteins and their encoding genes in Arabidopsis thaliana. BMC Genomics 9:118

Ishikawa H, Evans ML (1993) The role of the distal elongation zone in the response of maize roots to auxin and gravity. Plant Physiol 102:1203-1210

Ishikawa S, Wagatsuma T (1998) Plasma membrane permeability of root-tip cells following temporary exposure to $\mathrm{Al}$ ions is a rapid measure of $\mathrm{Al}$ tolerance among plant species. Plant Cell Physiol 39:516-525
Ishitani M, Rao I, Wenzl P, Beebe S, Tohme J (2004) Integration of genomics approach with traditional breeding towards improving abiotic stress adaptation: drought and aluminum toxicity as case studies. Field Crops Res 90:35-45

Iuchi S, Kobayashi M, Yamaguchi-Shinozaki K, Shinozaki K (2000) A stress-inducible gene for 9-cisepoxycarotenoid dioxygenase involved in abscisic acid biosynthesis under water stress in drought-tolerant cowpea. Plant Physiol 123:553-562

Iuchi S, Kobayashi M, Taji T, Naramoto M, Seki M, Kato T, Tabata S, Kakubari Y, Yamaguchi-Shinozaki K, Shinozaki K (2001) Regulation of drought tolerance by gene manipulation of 9- cisepoxycarotenoid dioxygenase, a key enzyme in abscisic acid biosynthesis in Arabidopsis. Plant $\mathrm{J}$ 27:325-333

Johnson JJP, Carver BF, Baligar VC (1997) Productivity in Great Plains acid soils of wheat genotypes selected for aluminium tolerance. Plant Soil 188:101-106

Jozefaciuk G, Szatanik-Kloc A (2001) Aluminium-induced changes in the surface and micropore properties of wheat root: a study using water vapor adsorption desorption technique. Plant Soil 233:95-108

Kasai M, Sasaki M, Tanakamaru S, Yamamoto Y, Matsumoto H (1993) Possible involvement of abscisic acid in increases in activities of two vacuolar $\mathrm{H}^{+}$-pumps in barley roots under aluminum stress. Plant Cell Physiol 34:1335-1338

Kell DB (2011) Breeding crop plants with deep roots: their role in sustainable carbon, nutrient and water sequestration. Ann Bot 108:407-418

Khan MS, Tawaraya K, Sekimoto H, Koyama H, Kobayashi Y, Murayama T, Chuba M, Kambayashi M, Shiono Y, Uemura M, Ishikawa S, Wagatsuma T (2009) Relative abundance of $\Delta 5$-sterols in plasma membrane lipids of root-tip cells correlates with aluminum tolerance of rice. Physiol Plant 135:73-83

Kochian LV, Hoekenga OA, Piñeros MA (2004) How do crop plants tolerate acid soils? Mechanisms of aluminum tolerance and phosphorous efficiency. Annu Rev Plant Biol 55:459-493

Kollmeier M, Felle HH, Horst WJ (2000) Genotypical differences in aluminum resistance of maize are expressed in the distal part of the transition zone. Is reduced basipetal auxin flow involved in inhibition of root elongation by aluminum? Plant Physiol 122:945-956

Krizek DT, Foy CD (1988a) Role of water stress in differential aluminum tolerance of two barley cultivars grown in an acid soil. J Plant Nutr 11:351-367

Krizek DT, Foy CD (1988b) Mineral element concentration of six sunflower cultivars in relation to water deficit and aluminum toxicity. J Plant Nutr 11:409-422

Krizek DT, Foy CD, Wergin WP (1988) Role of water stress in differential aluminum tolerance of six sunflower cultivars grown in an acid soil. J Plant Nutr 11:387-408

Kruger E, Sucoff E (1989) Growth and nutrient status of Quercus rubra $\mathrm{L}$. in response to $\mathrm{Al}$ and $\mathrm{Ca}$. J Exp Bot 40:653-658

Kuga S (1981) Pore size distribution analysis of gel substances by size exclusion chromatography. J Chromatogr A 206:449-461

Lagerwerff JV, Ogata G, Eagle HE (1961) Control of osmotic pressure of culture solutions with polyethylene glycol. Science 133:1486-1487 
Lawlor DW, Tezara W (2009) Causes of decreased photosynthetic rate and metabolic capacity in water-deficit leaf cells: a critical evaluation of mechanisms and integration of processes. Ann Bot 103:561-579

Layton BE, Boyd MB, Tripepi MS, Bitonti BM, Dollahon MNR, Balsamo RA (2010) Dehydration-induced expression of a 31-kda dehydrin in polypodium polypodioides (polypodiaceae) may enable large, reversible deformation of cell walls. Am J Bot 97:535-544

Le J, Vandenbussche F, Van Der Straeten D, Verbelen J-P (2001) In the early response of Arabidopsis roots to ethylene, cell elongation is up- and down regulated and uncoupled from differentiation. Plant Physiol 125:519-522

LeNoble ME, Spollen WG, Sharp RE (2004) Maintenance of shoot growth by ABA: genetic assessment of the role of ethylene suppression. J Exp Bot 55:237-245

Leucci MR, Lenucci MS, Piro G, Dalessandro G (2008) Water stress and cell wall polysaccharides in the apical root zone of wheat cultivars varying in drought tolerance. J Plant Physiol 165:1168-1180

Lidon FC, Barreiro MJ, Ramalho JC, Lauriano JA (1999) Effects of aluminum toxicity on nutrient accumulation in maize shoots: implications on photosynthesis. J Plant Nutr 22:397-416

Ma JF, Shen RF, Nagao S, Tanimoto E (2004) Aluminum targets elongating cells by reducing cell wall extensibility in wheat roots. Plant Cell Physiol 45:583-589

Magalhaes JV, Liu J, Guimarães CT, Lana UG, Alves VM, Wang YH, Schaffert RE, Hoekenga OA, Piñeros MA, Shaff JE, Klein PE, Carneiro NP, Coelho CM, Trick HN, Kochian LV (2007) A gene in the multidrug and toxic compound extrusion (MATE) family confers aluminum tolerance in sorghum. Nat Genet 39:1156-1161

Maison A, Bertsch PM (1997) Aluminium speciation in the presence of wheat root cell walls: a wet chemical study. Plant Cell Environ 20:504-512

Manavalan LP, Guttikonda SK, Tran L-SP, Nguyan HT (2009) Physiological and molecular approaches to improve drought resistance in soybean. Plant Cell Physiol 50:1260-1276

Maron LG, Piñeros MA, Guimarães CT, Magalhaes JV, Pleiman JK, Mao C, Shaff J, Belicuas SN, Kochian LV (2010) Two functionally distinct members of the MATE (multi-drug and toxic compound extrusion) family of transporters potentially underlie two major aluminum tolerance QTLs in maize. Plant J 61:728-740

Marschner H (1995) Mineral nutrition of higher plants, 2nd edn. Academic Press, London

Massot N, Nicander B, Barceló J, Poschenrieder C, Tillberg E (2002) A rapid increase in cytokinin levels and enhanced ethylene evolution precede $\mathrm{Al}^{3+}$-induced inhibition of root growth in bean seedlings (Phaseolus vulgaris L.). Plant Growth Regul 37:105-112

McQueen-Mason SJ, Rochange F (1999) Expansins in plant growth and development: an update on an emerging topic. Plant Biol 1:19-25

Meda AR, Furlani PR (2005) Tolerance to aluminium toxicity by tropical leguminous plants used as cover crops. Braz Arch Biol Techol 48:309-317

Miklas PN, Kelly JD, Beebe SE, Blair MW (2006) Common bean breeding for resistance against biotic and abiotic stresses: from classical to MAS breeding. Euphytica 147:105-131
Milla MA, Butler E, Huete AR, Wilson CF, Anderson O, Gustafson JP (2002) Expressed sequence tag-based gene expression analysis under aluminum stress in rye. Plant Physiol 130:1706-1716

Mir RR, Allah MZ, Sreenivasulu N, Trethowan T, Varshney RK (2012) Integrated genomics, physiology and breeding approaches for improving drought tolerance in crops. Theor Appl Genet 125:625-645

Mittler R (2006) Abiotic stress, the field environment and stress combination. Trends Plant Sci 11:15-19

Mittler R, Blumwald E (2010) Genetic engineering for modern agriculture: challenges and perspectives. Annu Rev Plant Biol 61:443-462

Miyasaka SC, Buta JG, Howell RK, Foy CD (1991) Mechanisms of aluminum tolerance in snapbeans. Root exudation of citric acid. Plant Physiol 96:737-743

Moore JP, Nguema-Ona E, Chevalier L, Lindsey GG, Brandt WF, Lerouge P, Farrant JM, Driouich A (2006) Response of the leaf cell wall to desiccation in the resurrection plant Myrothamnus flabellifolius. Plant Physiol 141:651-662

Moore JP, Farrant JM, Driouich A (2008a) A role for pectinassociated arabinans in maintaining the flexibility of the plant cell wall during water deficit stress. Plant Signal Behav 3:102-104

Moore JP, Vicré-Gibouin M, Farrant JM, Driouich A (2008b) Adaptations of higher plant cell walls to water loss: drought vs desiccation. Physiol Plant 134:237-245

Mossor-Pietraszewska T (2001) Effect of aluminum on plant growth and metabolism. Acta Biochim Pol 48:673-686

Moubayidin L, Di Mambro R, Sabatini S (2009) Cytokininauxin crosstalk. Trends Plant Sci 14:557-562

Neumann PM (2008) Coping mechanism for crop plants in drought-prone environments. Ann Bot 101:901-907

Nian H, Yang ZM, Huang H, Yan X, Mastrumoto H (2004) Combined effect of short-term water deficit stress and aluminum toxicity on citrate secretion from soybean roots. J Plant Nutr 27:1281-1293

Okiyo T, Gudu S, Kiplagat O, Owuoche J (2010) Combining drought and aluminium toxicity tolerance to improve Sorghum productivity. Afr Crop Sci J 18:147-154

Orellana S, Yañez M, Espinoza A, Verdugo I, González E, RuizLara S, Casaretto JA (2010) The transcription factor SlAREB1 confers drought, salt stress tolerance and regulates biotic and abiotic stress-related genes in tomato. Plant Cell Environ 33:2191-2208

Pereira WE, de Siqueira DL, Martinez CA, Puiatti M (2000) Gas exchange and chlorophyll fluorescence in four citrus rootstocks under aluminum stress. J Plant Physiol 157:513-520

Porter WM, Wilson IR (1984) Soil acidity in the eastern wheat belt. J Agric West Aust 25:132-135

Qin X, Zeevaart JAD (1999) The 9-cis-epoxycarotenoid cleavage reaction is the key regulatory step of abscisic acid biosynthesis in water-stressed bean. Proc Natl Acad Sci USA 96:15354-15361

Qin X, Zeevaart JA (2002) Overexpression of a 9- cisepoxycarotenoid dioxygenase gene in Nicotiana plumbaginifolia increases abscisic acid and phaseic acid levels and enhances drought tolerance. Plant Physiol 128:544-551

Rajashekar CB, Lafta A (1996) Cell-wall changes and cell tension in response to cold acclimation and exogenous abscisic acid in leaves and cell cultures. Plant Physiol 111:605-612 
Rangel AF, Rao IM, Horst WJ (2007) Spatial aluminium sensitivity of root apices of two common bean (Phaseolus vulgaris L.) genotypes with contrasting aluminium resistance. J Exp Bot 58:3895-3904

Rangel AF, Rao IM, Braun H-P, Horst WJ (2010) Aluminium resistance in common bean (Phaseolus vulgaris) involves induction and maintenance of citrate exudation from root apices. Physiol Plant 138:176-190

Rao IM (2001) Role of physiology in improving crop adaptation to abiotic stresses in the tropics: the case of common bean and tropical forages. In: Pessarakli M (ed) Handbook of plant and crop physiology. Marcel Dekker, New York, pp 583-613

Rao IM, Zeigler RS, Vera R, Sarkarung S (1993) Selection and breeding for acid-soil tolerance in crops. BioScience 43:454-465

Rao IM, Miles JW, Granobles JC (1998) Differences in tolerance to infertile acid soil stress among germplasm accessions and genetic recombinants of the tropical forage grass genus, Brachiaria. Field Crops Res 59:43-52

Rao IM, Beebe S, Ricaurte J, Teran H, Singh S (2004) Common bean (Phaseolus vulgaris L.) genotypes tolerant to aluminum-toxic soils in the tropics. Proceedings of the 6th International Symposium on Plant-Soil Interactions at Low pH (PSILPH) held in Sendai, Japan from 31 July to 5 August, 2004. Japanese Society of Soil Science and Plant Nutrition, Sendai, Japan, pp 72-273

Rao IM, Beebe SE, Polanía J, Grajales M, Cajiao C, García R, Ricaurte J, Rivera M (2009) Physiological basis of improved drought resistance in common bean: the contribution of photosynthate mobilization to grain. Paper presented at Interdrought III: the 3rd International Conference on Integrated Approaches to Improve Crop Production Under DroughtProne Environments, October 11-16, 2009, Shanghai Academy of Agriculture Science, Shanghai, China

Rao I, Miles J, Wenzl P, Louw-Gaume A, Cardoso JA, Ricaurte J, Polania J, Rincon J, Hoyos V, Frossard E, Wagatsuma T, Horst W (2011) Mechanisms of adaptation of brachiariagrasses to abiotic stress factors in the tropics. Plenary paper presented at the III International Symposium on Forage Breeding held at Bonito, MS, Brazil, 7 to 11 November 2011. Published by the Symposium organizer as CDROM, pp 361-383

Rengel Z (1996) Uptake of aluminium by plant cells. New Phytol 134:389-406

Rosales MA, Ocampo E, Rodríguez-Valentín R, Olvera-Carrillo Y, Acosta-Gallegos J, Covarrubias AA (2012) Physiological analysis of common bean (Phaseolus vulgaris L.) cultivars uncovers characteristics related to terminal drought resistance. Plant Physiol Biochem 56:24-34

Rose JK, Braam J, Fry SC, Nishitani K (2002) The XTH family of enzymes involved in xyloglucan endotransglucosylation and endohydrolysis: current perspectives and a new unifying nomenclature. Plant Cell Physiol 43:1421-1435

Rose JKC, Bashir S, Giovannoni JJ, Jahn MM, Saravanan RS (2004) Tackling the plant proteome: practical approaches, hurdles and experimental tools. Plant J39:715-733

Růžička K, Ljung K, Vanneste S, Podhorská R, Beeckman T, Friml J, Benková E (2007) Ethylene regulates root growth through effects on auxin biosynthesis and transportdependent auxin distribution. Plant Cell 19:2197-2212

Růžička K, Šimášková M, Duclercq J, Petrášek J, Zažímalová E, Simon S, Friml J, Van Montagu MC, Benková E (2009)
Cytokinin regulates root meristem activity via modulation of the polar auxin transport. Proc Natl Acad Sci USA 106:4284-4289

Ryan PR, DiTomaso JM, Kochian LV (1993) Aluminium toxicity in roots: an investigation of spatial sensitivity and the role of the root cap. J Exp Bot 44:437-446

Ryan PR, Delhaize E, Randall PJ (1995) Characterization of Alstimulated efflux of malate from the apices of Al-tolerant wheat roots. Planta 196:103-110

Saab IN, Sharp RE, Pritchard J (1992) Effect of inhibition of abscisic acid accumulation on the spatial distribution of elongation in the primary root and mesocotyl of maize at low water potentials. Plant Physiol 99:26-33

Sardans J, Peñuelas J (2007) Drought changes the dynamics of trace element accumulation in a Mediterranean Quercus ilex forest. Environ Pollut 147:567-583

Sasidharan R, Voesenek LACJ, Pierik R (2011) Cell wall modifying proteins mediate plant acclimatization to biotic and abiotic stresses. Crit Rev Plant Sci 30:548-562

Schachtman DP, Goodger JQD (2008) Chemical root to shoot signaling under drought. Trends Plant Sci 13:281-287

Schier GA, McQuattie CJ (2000) Effect of water stress on aluminum toxicity in pitch pine seedlings. J Plant Nutr 23:637-647

Schmohl N, Horst WJ (2000) Cell wall pectin content modulates aluminium sensitivity of Zea mays (L.) cell grown in suspension culture. Plant Cell Environ 23:735-742

Schopfer P (2006) Biomechanics of plant growth. Am J Bot 93:1415-1425

Seiler C, Harshavardhan VT, Rajesh K, Reddy PS, Strickert M, Rolletschek H, Scholz U, Wobus U, Sreenivasulu N (2011) ABA biosynthesis and degradation contributing to ABA homeostasis during barley seed development under control and terminal drought-stress conditions. J Exp Bot 62:2615-2632

Seo M, Koshiba T (2002) Complex regulation of ABA biosynthesis in plants. Trends Plant Sci 7:41-48

Seo M, Koiwai H, Akaba S, Komano T, Oritani T, Kamiya Y, Koshiba T (2000) Abscisic aldehyde oxidase in leaves of Arabidopsis thaliana. Plant J 23:481-488

Sharp RE (2002) Interaction with ethylene: changing views on the role of $\mathrm{ABA}$ in root and shoot growth responses to water stress. Plant Cell Environ 25:211-222

Sharp RE, Davies WJ (1989) Regulation of growth and development of plants growing with a restricted supply of water. In: Jones HG, Flowers TL, Jones MB (eds) Plants under stress. Cambridge University Press, Cambridge, pp 71-93

Sharp RE, Silk WK, Hsiao TC (1988) Growth of the maize primary root at low water potentials: I. Spatial distribution of expansive growth. Plant Physiol 87:50-57

Sharp RE, LeNoble ME, Else MA, Thorne ET, Gherardi F (2000) Endogenous ABA maintains shoot growth in tomato independently of effects on plant water balance: evidence for an interaction with ethylene. J Exp Bot 51:1575-1584

Sharp RE, Poroyko V, Hejlek LG, Spollen WG, Springer GK, Bohnert HJ, Nguyen HT (2004) Root growth maintenance during water deficits: physiology to functional genomics. J Exp Bot 55:2343-2351

Shen H, Ligaba A, Yamaguchi M, Osawa H, Shibata K, Yan X, Matsumoto H (2004) Effect of K-252a and abscisic acid on the efflux of citrate from soybean roots. J Exp Bot 55:663-671 
Shen H, Hou NY, Schlicht M, Wan YL, Mancuso S, Baluska F (2008) Aluminium toxicity targets PIN2 in Arabidopsis root apices: effects on PIN2 endocytosis, vesicular recycling, and polar auxin transport. Chin Sci Bull 53:24802487

Shimazaki Y, Ookawa T, Hirasawa T (2005) The root tip and accelerating region suppress elongation of the decelerating region without any effects on cell turgor in primary roots of maize under water stress. Plant Physiol 139:458-465

Shinozaki K, Yamaguchi-Shinozaki K (1997) Gene expression and signal transduction in water-stress response. Plant Physiol 115:327-334

Shinozaki K, Yamaguchi-Shinozaki K (2007) Gene networks involved in drought stress response and tolerance. J Exp Bot 58:221-227

Simon L, Smalley TJ, Jones JB Jr, Lasseigne FT (1994a) Aluminum toxicity in tomato. Part 1 . Growth and mineral nutrition. J Plant Nutr 17:293-306

Simon L, Smalley TJ, Jones JB Jr, Lasseigne FT (1994b) Aluminum toxicity in tomato. Part 2. Leaf gas exchange, chlorophyll content, and invertase activity. J Plant Nutr 17:307-317

Sivaguru M, Horst WJ (1998) The distal part of the transition zone is the most aluminum-sensitive apical root zone of maize. Plant Physiol 116:155-163

Sivaguru M, Ezaki B, He ZH, Tong H, Osawa H, Baluška F, Volkmann D, Matsumoto H (2003) Aluminum-induced gene expression and protein localization of a cell wallassociated receptor kinase in Arabidopsis. Plant Physiol 132:2256-2266

Sivaguru M, Horst WJ, Eticha D, Matsumoto H (2006) Aluminum inhibits apoplastic flow of high-molecular weight solutes in root apices of Zea mays L. J Plant Nutr Soil Sci 169:679-690

Slugeňová K, Ditmarová L', Kurjak D, Vál'ka J (2011) Drought and aluminium as stress factors in Norway spruce (Picea abies [L.] Karst) seedlings. J For Sci 57:547-554

Spollen WG, Shartp RE, Saab IN, Wu Y (1993) Regulation of cell expansion in roots and shoots at low water potentials. In: Smith JAC, Griffiths H (eds) Water deficits. Plant responses from cell to community. Bios Scientific Publishers, Oxford, pp 37-52

Spollen WG, LeNoble ME, Samuels TD, Bernstein N, Sharp RE (2000) Abscisic acid accumulation maintains maize primary root elongation at low water potentials by restricting ethylene production. Plant Physiol 122:967-976

Sponchiado BN, White JW, Castillo JA, Jones PG (1989) Root growth of four common bean cultivars in relation to drought tolerance in environments with contrasting soil types. Exp Agric 25:249-257

Staß A, Horst WJ (2009) Callose in abiotic stress. In: Bacic A, Fincher GB, Stone BA (eds) Chemistry, biochemistry, and biology of $(1 \rightarrow 3)$ - $\beta$-glucans and related polysaccharides. Academic, Burlington, pp 499-524

Stepanova AN, Yun J, Likhacheva AV, Alonso JM (2007) Multilevel interactions between ethylene and auxin in Arabidopsis roots. Plant Cell 19:2169-2185

Stodart BJ, Raman H, Coombes N, Mackay M (2007) Evaluating landraces of bread wheat Triticum aestivum L. for tolerance to aluminum under low $\mathrm{pH}$ conditions. Genet Resour Crop Evol 54:759-766
Sumner ME, Shahandeh H, Bouton J, Hammel J (1986) Amelioration of an acid soil profile through deep liming and surface application of gypsum. Soil Sci Soc Am J 50:1254-1258

Sun P, Tian QY, Zhao MG, Dai XY, Huang JH, Li LH, Zhang WH (2007) Aluminum-induced ethylene production is associated with inhibition of root elongation in Lotus japonicus L. Plant Cell Physiol 48:1229-1235

Sun P, Tian QY, Chen J, Zhang WH (2010) Aluminium-induced inhibition of root elongation in Arabidopsis is mediated by ethylene and auxin. J Exp Bot 61:347-356

Swarup R, Perry P, Hagenbeek D, Van Der Straeten D, Beemster GT, Sandberg G, Bhalerao R, Ljung K, Bennett MJ (2007) Ethylene upregulates auxin biosynthesis in Arabidopsis seedlings to enhance inhibition of root cell elongation. Plant Cell 19:2186-2196

Tabuchi A, Matsumoto H (2001) Changes in cell-wall properties of wheat (Triticum aestivum) roots during aluminuminduced growth inhibition. Physiol Plant 112:353-358

Tabuchi A, Kikui S, Matsumoto H (2004) Differential effects of aluminium on osmotic potential and sugar accumulation in the root cells of Al-resistant and Al-sensitive wheat. Physiol Plant 120:106-112

Takei K, Yamaya T, Sakakibara H (2004) Arabidopsis CYP735A1 and CYP735A2 encode cytokinin hydroxylases that catalyze the biosynthesis of trans-Zeatin. J Biol Chem 279:41866-41872

Tamás L, Huttová J, Mistrík I, Šimonovičová M, Široká M (2006) Aluminium-induced drought and oxidative stress in barley roots. J Plant Physiol 163:781-784

Tang C, Diatloff E, Rengel Z, McGann B (2001) Growth response to subsurface soil acidity of wheat genotypes differing in aluminium tolerance. Plant Soil 236:1-10

Tang C, Rengel Z, Abrecht D, Tennant D (2002) Aluminiumtolerant wheat uses more water and yields higher than aluminium-sensitive one on a sandy soil with subsurface acidity. Field Crop Res 78:93-103

Tang C, Asseng S, Diatloff E, Rengel Z (2003a) Modelling yield losses of aluminium-resistant and aluminium-sensitive wheat due to subsurface soil acidity: effects of rainfall, liming and nitrogen application. Plant Soil 254:349-360

Tang C, Nuruzzaman M, Rengel Z (2003b) Screening wheat genotypes for tolerance of soil acidity. Aust J Agric Res $54: 445-452$

Tang C, Rengel Z, Diatloff E, Gazey C (2003c) Responses of wheat and barley to liming on a sandy soil with subsoil acidity. Field Crop Res 80:235-244

The C, Calba H, Horst WJ, Zonkeng C (2001) Maize grain yield correlated responses to change in acid soil characteristics after 3 years of soil amendments. Seventh Eastern and Southern Africa Regional Maize Conference. 11th to 15th February 2001, pp 222-227

The C, Calba H, Zonkeng C, Ngonkeu ELM, Adetimirin VO, Mafouasson HA, Meka SS, Horst WJ (2006) Responses of maize grain yield to changes in acid soil characteristics after soil amendments. Plant Soil 284:45-57

The C, Meka SS, Ngonkeu ELM, Bell JM, Mafouasson HA, Menkir A, Calba H, Zonkeng C, Atemkeng M, Horst WJ (2012) Maize grain yield responses to changes in acid soil characteristics with yearly leguminous crop rotation, fallow, slash, burn and liming practices. Int J Plant Soil Sci 1:1-15 
Thompson AJ, Jackson AC, Parker RA, Morpeth DR, Burbidge A, Taylor IB (2000) Abscisic acid biosynthesis in tomato: regulation of zeaxanthin epoxidase and 9-cis- epoxycarotenoid dioxygenase mRNAs by light/dark cycles, water stress and abscisic acid. Plant Mol Biol 42:833-845

Trachsel S, Stamp P, Hind A (2010) Effect of high temperatures, drought and aluminum toxicity on root growth of tropical maize (Zea mays L.) seedlings. Maydica 55:249-260

Veslues P, Ober E, Sharp R (1998) Root growth and oxygen relations at low water potentials: impact of oxygen availability in polyethylene glycol solutions. Plant Physiol 116:1403-1412

Vierstra R, Haug A (1978) The effect of $\mathrm{Al}^{3+}$ on the physical properties of membrane lipids in Thermoplasma acidophilum. Biochem Biophys Res Commun 84:138-143

Vissenberg K, Martinez-Vilchez IM, Verbelen JP, Miller JG, Fry SC (2000) In vivo colocalization of xyloglucan endotransglycosylase activity and its donor substrate in the elongation zone of Arabidopsis roots. Plant Cell 12:12291237

Voesenek LA, Benschop JJ, Bou J, Cox MC, Groeneveld HW, Millenaar FF, Vreeburg RA, Peeters AJ (2003) Interactions between plant hormones regulate submergence-induced shoot elongation in the flooding-tolerant dicot Rumex palustris. Ann Bot 91:205-211

von Uexküll HR, Mutert E (1995) Global extent, development and economic impact of acid soils. Plant Soil 171:1-15

Wagatsuma T, Ishikawa S, Uemura M, Mitsuhashi W, Kawamura T, Khan MSH, Tawaraya K (2005) Plasma membrane lipids are the powerful components for early stage aluminum tolerance in triticale. Soil Sci Plant Nutr 51:701-704

Wang KLC, Li H, Ecker JR (2002) Ethylene biosynthesis andsignaling networks. Plant Cell 14:S131-S151

Wang JP, Raman H, Zhang GP, Mendham N, Zhou MX (2006) Aluminium tolerance in barley (Hordeum vulgare L.): physiological mechanisms, genetics and screening methods. J Zhejiang Univ-Sc B 7:769-787

Waraich EA, Ahmad R, Saifullah, Ashraf MY, Ehsanullah (2011) Role of mineral nutrition in alleviation of drought stress in plants. AJCS 5:764-777

Wasson AP, Richards RA, Chatrath R, Misra SC, Prasad SV, Rebetzke GJ, Kirkegaard JA, Christopher J, Watt M (2012) Traits and selection strategies to improve root systems and water uptake in water-limited wheat crops. J Exp Bot 63:3485-3498

Watanabe T, Osaki M (2002) Role of organic acids in aluminum accumulation and plant growth in Melastoma malabathricum. Tree Physiol 22:785-792

Wehr JB, Menzies NW, Blamey FPC (2004) Inhibition of cellwall autolysis and pectin degradation by cations. Plant Physiol Biochem 42:485-492

Welcker C, Théc C, Andréau B, De Leon C, Parentoni SN, Bernal J, Félicité J, Zonkeng C, Salazar F, Narro L, Charcosset A, Horst WJ (2005) Heterosis and combining ability for maize adaptation to tropical acid soils: implications for future breeding strategies. Crop Sci 45:2405-2413

Werner T, Motyka V, Strnad M, Schmülling T (2001) Regulation of plant growth by cytokinin. Proc Natl Acad Sci USA 98:10487-10492

Whitmore AP, Whalley WR (2009) Physical effects of soil drying on roots and crop growth. J Exp Bot 60:2845-2857
Wilkinson S, Davies WJ (2002) ABA-based chemical signalling: the co-ordination of responses to stress in plants. Plant Cell Environ 25:195-210

Wilkinson S, Kudoyarova GR, Veselov DS, Arkhipova TN, Davies WJ (2012) Plant hormone interactions: innovative targets for crop breeding and management. J Exp Bot 63:3499-3509

Wissemeier AH, Klotz F, Horst WJ (1987) Aluminium induced callose synthesis in roots of soybean (Glycine $\max \mathrm{L}$.). J Plant Physiol 129:487-492

Wolters H, Jürgens G (2009) Survival of the flexible: hormonal growth control and adaptation in plant development. Nat Rev Genet 10:305-317

Wortmann CS, Kirkby RA, Eledu CA, Allan DJ (1998) Atlas of common bean (Phaseolus vulgaris L.) production in Africa. CIAT publication no. 297. Cali, Colombia

Wu Y, Cosgrove DJ (2000) Adaptation of roots to low water potentials by changes in cell wall extensibility and cell wall proteins. J Exp Bot 51:1543-1553

Xiao XX (2002) The physiological and biochemical response of longan (Dimocarpus longan Lour.) to aluminum stress and rectification of aluminum toxicity. Fujian J Agric Sci 17:182-185

Yamaguchi M, Sharp RE (2010) Complexity and coordination of root growth at low water potentials: recent advances from transcriptomic and proteomic analyses. Plant Cell Environ 33:590-603

Yamaguchi M, Valliyodan B, Zhang J, Lenoble ME, Yu O, Rogers EE, Nguyen HT, Sharp RE (2010) Regulation of growth response to water stress in the soybean primary root. I. Proteomic analysis reveals region-specific regulation of phenylpropanoid metabolism and control of free iron in the elongation zone. Plant Cell Environ 33:223-243

Yang Z, Sivaguru M, Horst WJ, Matsumoto H (2000) Aluminium tolerance is achieved by exudation of citric acid from roots of soybean (Glycine max). Physiol Plant 110:72-77

Yang JL, Li YY, Zhang YJ, Zhang SS, Wu YR, Wu P, Zheng SJ (2008) Cell wall polysaccharides are specifically involved in the exclusion of aluminum from the rice root apex. Plant Physiol 146:602-611

Yang ZB, You JF, Xu MY, Yang ZM (2009) Interaction between aluminum toxicity and manganese toxicity in soybean (Glycine max). Plant Soil 319:277-289

Yang ZB, Eticha D, Rao IM, Horst WJ (2010) Alteration of cellwall porosity is involved in osmotic stress-induced enhancement of aluminium resistance in common bean (Phaseolus vulgaris L.). J Exp Bot 61:3245-3258

Yang JL, Zhu XF, Peng YX, Zheng C, Li GX, Liu Y, Shi YZ, Zheng SJ (2011a) Cell wall hemicellulose contributes significantly to aluminum adsorption and root growth in Arabidopsis. Plant Physiol 155:1885-1892

Yang XY, Yang JL, Zhou Y, Piñeros MA, Kochian LV, Li GX, Zheng SJ (2011b) A de novo synthesis citrate transporter, Vigna umbellata multidrug and toxic compound extrusion, implicates in Al-activated citrate efflux in rice bean (Vigna umbellata) root apex. Plant Cell Environ 34:2138-2148

Yang ZB, Eticha D, Rotter B, Rao IM, Horst WJ (2011c) Physiological and molecular analysis of polyethylene glycol-induced reduction of aluminium accumulation in the root tips of common bean (Phaseolus vulgaris). New Phytol 192:99-113 
Yang ZB, Eticha D, Albacete A, Rao IM, Roitsch T, Horst WJ (2012) Physiological and molecular analysis of the interaction between aluminium toxicity and drought stress in common bean (Phaseolus vulgaris). J Exp Bot 63:3109-3125

Yokosho K, Yamaji N, Ma JF (2011) An Al-inducible MATE gene is involved in external detoxification of $\mathrm{Al}$ in rice. Plant J 68:1061-1069

Zhang X-B, Liu P, Yang YS, Xu G-D (2007) Effect of Al in soil on photosynthesis and related morphological and physiological characteristics of two soybean genotypes. Bot Stud 48:435-444
Zhao X-J, Sucoff E, Stadelmann EJ (1987) $\mathrm{Al}^{3+}$ and $\mathrm{Ca}^{2+}$ alteration of membrane permeability of Quercus rubra root cortex cells. Plant Physiol 83:159-162

Zhu XF, Shi YZ, Lei GJ, Fry SC, Zhang BC, Zhou YH, Braam J, Jiang T, Xu XY, Mao CZ, Pan YJ, Yang JL, Wu P, Zheng SJ (2012) XTH31, encoding an in vitro XEH/XET-active enzyme, regulates aluminum sensitivity by modulating in vivo XET action, cell wall xyloglucan content, and aluminum binding capacity in Arabidopsis. Plant Cell. doi:http:// dx.doi.org/10.1105/tpc.112.106039 